\title{
Evolution, Discovery, and Interpretations of Arthropod Mushroom Bodies
} \author{
and Kei Ito 3,4 \\ ${ }^{1}$ Arizona Research Laboratories Division of Neurobiology \\ University of Arizona \\ Tucson, Arizona 85721 USA \\ ${ }^{2}$ Department of Ecology and Evolutionary Biology \\ University of Arizona \\ Tucson, Arizona 85721 USA \\ ${ }^{3}$ Yamamoto Behavior Genes Project \\ ERATO (Exploratory Research for Advanced Technology) \\ Japan Science and Technology Corporation (JST) \\ at Mitsubishi Kasei Institute of Life Sciences \\ 194 Machida-shi, Tokyo, Japan
}

Nicholas J. Strausfeld, ${ }^{1,2,5}$ Lars Hansen, ${ }^{1}$ Y ongsheng Li, ${ }^{1}$ Robert S. Gomez, ${ }^{1}$

\begin{abstract}
Mushroom bodies are prominent neuropils found in annelids and in all arthropod groups except crustaceans. First explicitly identified in 1850, the mushroom bodies differ in size and complexity between taxa, as well as between different castes of a single species of social insect. These differences led some early biologists to suggest that the mushroom bodies endow an arthropod with intelligence or the ability to execute voluntary actions, as opposed to innate behaviors. Recent physiological studies and mutant analyses have led to divergent interpretations. One interpretation is that the mushroom bodies conditionally relay to higher protocerebral centers information about sensory stimuli and the context in which they occur. Another interpretation is that they play a central role in learning and memory. Anatomical studies suggest that arthropod mushroom bodies are predominately associated with olfactory pathways except in phylogenetically basal insects. The prominent olfactory input to the mushroom body calyces in more recent
\end{abstract}

${ }^{4}$ Present address: National Institute for Basic Biology, Myodaiji-cho, Japan.

${ }^{5}$ Corresponding author. insect orders is an acquired character. An overview of the history of research on the mushroom bodies, as well as comparative and evolutionary considerations, provides a conceptual framework for discussing the roles of these neuropils.

\section{Introduction}

Mushroom bodies are lobed neuropils that comprise long and approximately parallel axons originating from clusters of minute basophilic cells located dorsally in the most anterior neuromere of the central nervous system. Structures with these morphological properties are found in many marine annelids (e.g., scale worms, sabellid worms, nereid worms) and almost all the arthropod groups, except crustaceans. The most primitive lobopods, the Onychophora (velvet worms), possess these structures as well as the most advanced social insects.

Like all other parts of an organism, mushroom bodies are the products of evolution. Their structure and functions reflect their evolutionary history and the specific sensory and behavioral adaptations that characterize a particular taxon. Present understanding and interpretations of mushroom body function also reflect the evolution of research on insect brain and behavior, which has resulted in disparate views of mushroom body function. One view holds that mushroom bodies are the site of olfactory learning and memory. Another view is

LEARN IN G \& MEM ORY 5:11-37 @ 1998 by Cold Spring Harbor Laboratory Press ISSN 1072-0502/98 \$5.00

$$
\begin{array}{llllllllllllllll}
L & E & A & R & N & I & N & G & \underset{\mathbf{1 1}}{\boldsymbol{X}} & M & E & M & O & R & Y
\end{array}
$$


Strausfeld et al.

that they support a variety of other functions, not all necessarily represented in the same species. Such functions include sensory discrimination and integration with other modalities, the control of complex behavioral repertoires, and spatial orientation.

\section{EARLY HISTORY OF MUSHROOM BODY RESEARCH}

Mushroom bodies were discovered in 1850 by the French biologist Félix Dujardin, who called these structures corps pédonculés, likening their appearance to the fruiting bodies of lichens. Many recent accounts have co-opted Dujardin's paper in support of the widely held belief that mushroom bodies are learning and memory centers. How ever, Dujardin did not suggest this, but proposed that these centers endowed an insect with a degree of free will or intelligent control over instinctive actions. He supported this idea from comparative studies of the brains of ichneumons, solitary bees, and honeybees, showing that advancing sociality was correlated with the possession of enlarged mushroom bodies (Dujardin 1850). He observed that insects with small mushroom bodies showed greater coordination of thoracic motor actions after decapitation than did insects with large mushroom bodies and proposed that the smaller the mushroom body, the more automatic or instinctive that insect's behavior. Dujardin also carried out experiments on homing abilities in ants (Dujardin 1853 ) to underpin his ideas of insect intelligence. Two other French biologists, Faivre (1857) and Binet (1894), furthered Dujardin's ideas, performing sophisticated ablation experiments to demonstrate that although the suboesophageal ganglion is necessary for maintaining synchronized movements of the limbs (Faivre showed that, if fed, a dytiscid beetle can survive for months without its supraesophageal ganglion), it was insufficient for providing complex and varying patterns of motor activity. Faivre, in particular, demonstrated these complex movements to be under the control of the supraesophageal ganglion (the brain proper). Several other 19th century studies supported the idea that mushroom bodies of insects mediate intelligent versus innate behavior on the basis of comparative anatomy, with particular emphasis on the social Hymenoptera and the differences between the brains of different castes (Leydig 1864; Forel 1874; Flögel 1876, 1878). Like Dujardin's, none of these studies explicitly suggested that the mushroom bodies underlie learning and memory.
Flögel (1876) was the first to define criteria for identifying mushroom bodies across insect species: the presence in the supraoesophageal mass of paired groups of several hundred to several hundred thousand minute cells (termed globuli cells but now known as Kenyon cells; Strausfeld 1976) that surmount lobed neuropils that Flögel proposed were composed of parallel fibers. Kenyon (1896a,b), who was the first to use Golgi methods on insect brains, confirmed Flögel's ideas about the fibrous nature of globuli cell morphology. Kenyon showed that the dendritic branches of globuli cells invade the head of the mushroom body to form a structure called the calyx. He described the parallel axons of globuli cells forming a pedunculus that extends to the front of the brain where axons then branch to provide a vertical and a medial lobe (Kenyon 1896a,b). Kenyon identified afferents to the calyces and suggested that these carried olfactory, visual, and tactile information. He proposed that mushroom bodies provided a center for sensory-motor integration, quite separate from direct sensory-motor relays that characterize other brain areas or thoracic or abdominal ganglia (Kenyon 1896a). Kenyon did not suggest that mushroom bodies are involved in learning and memory.

Golgi studies on the mushroom bodies of Blattodea (cockroaches: Sanchez 1933), Hemiptera (true bugs: Pflugfelder 1937), and Hymenoptera (ants, wasps, bees: Goll 1967) all confirmed Kenyon's $(1896 a, b)$ findings, as have descriptions of these neuropils in the cricket Acheta domesticus (Schürmann 1973, 1974), the sphingid moths Sphinx ligustri (Pearson 1971) and Manduca sexta (Homberg et al. 1989), the house fly Musca domestica (Strausfeld 1976), and the honeybee Apis mellifera (Mobbs 1982, 1984).

\section{FIRST EVOLUTIONARY STUDIES}

Even before the advent in the early 1900s of methods that selectively reveal neural architecture (Cajal and de Castro 1933), early anatomists provided reasonably accurate descriptions of the mushroom bodies. Viallanes (1893), for example, was the first to recognize the enormous number of mushroom body globuli cells in the horseshoe crab Limulus, a feature that led the Sw edish neurologist Holmgren (1916) to wonder why this animal required such a huge center when, in his view, it so obviously lacked behavioral sophistication. Viallanes $(1887 a, b)$ also identified mushroom bodies in dragonflies, wasps, and crickets, thereby provid-

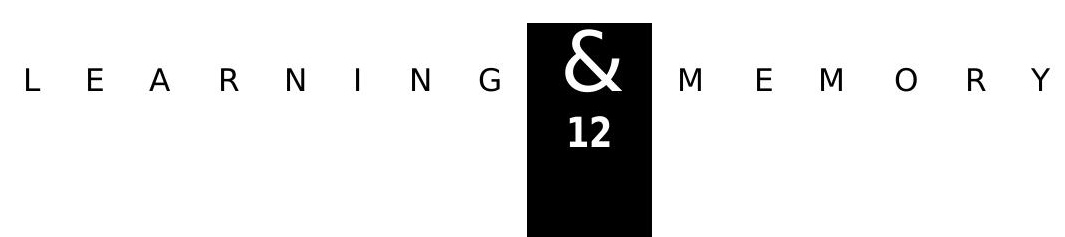


ing early comparative descriptions of this neuropil from sectioned material. Bretschneider (1913, $1914,1918,1924)$ published a series of studies on insect brains, including that of the cockroach Periplaneta orientalis (Bretschneider 1914) in which he identified the characteristic striations in the mushroom body lobes, now known to be caused by the layered arrangements of Kenyon cell axons (Li and Strausfeld 1997; Mizunami et al. 1997; Strausfeld 1998a,c). Like Flögel (1876), Bretschneider (1918) also attempted to use brain features for inferring insect relationships. How ever, the first attempt at constructing phylogenetic trees, on the basis of neural features, was Holmgren's (1916) elegant and systematic study of arthropod phylogeny from comparative brain anatomy. Significantly, Holmgren used Flögel's and Kenyon's anatomical criteria for identifying mushroom body-like neuropils in onychophorans, myriapods (centipedes and millipedes), chelicerates (e.g., horseshoe crabs, scorpions, whip spiders), and insects. His failure to find any correlation betw een caste status and the size of the mushroom bodies in termites (Holmgren 1909) reinforced Holmgren's opposition to the idea that mushroom bodies endowed an arthropod with intelligence. He found that cockroaches, near relatives of termites, had mushroom bodies almost as advanced (in cell number and gross morphology) as those of Hymenoptera. But not a keen observer of animal behavior, he wrote that "the psychic ability of the roach is hardly worth comparing with that of the termite."

The second serious attempt to reconstruct arthropod phylogeny from brain anatomy was by Holmgren's student Bertil Hanström who, in 1926 and 1928, based his theory of arthropod monophyly exclusively on features of the optic lobes and the occurrence of mushroom bodies (Fig. 1). Again, Hanström used mainly Flögel's and Kenyon's criteria but he also made a leap of faith regarding layered neuropils, called hemiellipsoid bodies, in the crustacean eye stalks, which he believed to be highly modified mushroom bodies (see below). A recent study (Strausfeld et al. 1995) reiterated this point of view, noting that hemiellip-

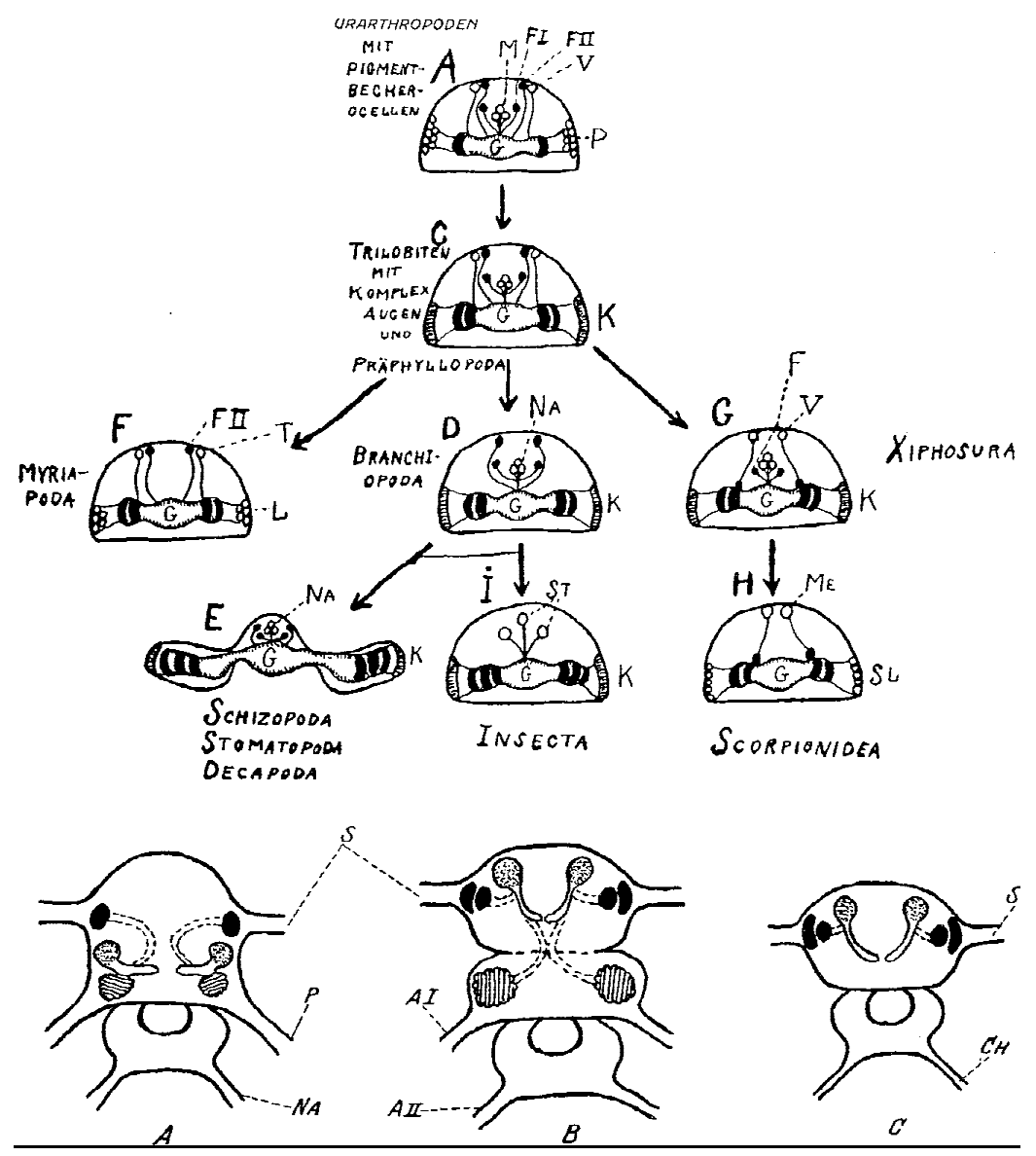

Figure 1: (Top) Hanström's classic 1926 paper claimed arthropod monophyly on the basis of observed similarities among visual systems. To accommodate mushroom bodies into this view (bottom) Hanström (1928) accorded them a primary function in both olfaction and vision. This allowed their seamless demonstration from annelids $(A)$ through to the araneans $(C$, bottom). Annelids, however, show no evidence of connections between visual neuropil and mushroom bodies. In Hanström's figure, the panel labeled arthropods $(B)$ depicts only two optic neuropils suggesting either a branchiopod crustacean or a thysanuran, either equipped with an insect-like mushroom body. However, mushroom bodies have not been identified in nonmalacostracans, and thysanurans lack olfactory glomeruli and calyces. 
Strausfeld et al.

soid bodies are supplied by first order olfactory neuropils, the antennule lobes (Mellon et al. 1992). However, studies on thalassinid crustaceans, in which the eyestalks are reduced or absent (e.g., the burrowing shrimp Callianassa; Strausfeld 1998b) have failed to resolve morphologies at all reminiscent of mushroom bodies even though in Callianassa the hemiellipsoid bodies reside within the brain proper.

\section{HISTORICAL ORIGIN OF THE CONCEPT OF MUSHROOM BODIES AS LEARNING AND MEMORY CENTERS}

Originating with Dujardin's 1850 paper, numerous early investigators attributed to the mushroom bodies a role in intelligent behavior. Particular significance was draw $\mathrm{n}$ from comparative studies of social Hymenoptera which were based on claims that the relatively large mushroom bodies of workers and queens served the broadest range of behaviors, as compared with, say, drones, which have relatively small mushroom bodies (Forel 1874; Jonescu 1909; von Alten 1910).

Suggestions that mushroom bodies play crucial roles in learning and memory are comparatively recent, deriving from lesioning experiments on ant mushroom bodies that perturbed the animal's ability to negotiate a maze using olfactory cues (Vowles 1964a). Ablations of the cockroach (Periplaneta) pedunculus and medial lobes, combined with place memory tests (Mizunami et al. 1993), have reinforced the possibility that the mushroom bodies may play a role in spatial orientation. Comparisons of mushroom body dimensions, foraging ranges, and behaviors in butterflies have also been used to suggest that these neuropils may be involved in spatial learning (Sivinski 1989).

The idea that mushroom bodies may harbor the cellular basis for associative memory originally derives from studies on honeybees by Menzel et al. (1974; see also Erber et al. 1980) and on Drosophila by Heisenberg (1980). In studies on honeybees, abolition of short-term olfactory memory was shown to be induced by cooling the vertical lobes and, along with them, the surrounding protocerebral neuropils (Erber et al. 1980). Studies on Drosophila involved the mutagenization of flies to isolate strains that are defective in odorant-driven behavior. Defective lines were subsequently examined for neural and molecular correlates (Quinn et al. 1974; for review, see Heisenberg 1998). A second strategy involved the mutagenization of flies to isolate structural brain mutants (Heisenberg 1980). Structurally defective lines were then screened for behavioral defects. Two of these mutations, mushroom bodies deranged and mushroom bodies reduced, have earned special attention (for review, see Heisenberg 1998) because structural defects of the mushroom bodies correlate with defects in olfactory conditioning (Heisenberg 1980, 1994; Heisenberg et al. 1985). Genetic and experimental induction of structural or biochemical defects, correlated with learning and memory deficits, have been invoked many times to support the possible role of the mushroom bodies in olfactory conditioning (Heisenberg et al. 1985; Nighorn et al. 1991; de Belle and Heisenberg 1994; Connolly et al. 1996), and the intellectual momentum in learning and memory research on insects during the last 25 years has largely been from such studies. The identification of substances in the mushroom bodies thought to be crucial in memory formation (for review, see Davis 1993) is germane to any discussion about cellular events underlying learning and memory. The significance of these works are review ed by Heisenberg (1998) and discussed by Ito et al. (1998).

\section{COMPARISONS BETWEEN MUSHROOM BODIES AND VERTEBRATE BRAIN CENTERS}

Dujardin (1850) was intrigued by the mushroom bodies because they reminded him of folds and gyri in the cerebral cortex. This comparison was taken up by subsequent investigators in the late 1800 s and early 1900 s, among them Hanström (1928) who suggested that mushroom bodies are analogous to the thalamus of fish. Comparisons with the vertebrate hippocampus have been proposed, because both the hippocampus and mushroom bodies may play roles in similar types of learning and memory, such as place memory in mammals (for review, see Muller 1996) and in cockroaches (Mizunami et al. 1993). It has been demonstrated that both hippocampus and Drosophila mushroom bodies show apparent elevation of expression of various learning-related molecules (for review, see Kandel and Abel 1995).

The characteristic cellular organization of the mushroom bodies, and their position in the olfactory pathway, have stimulated three other analogies: with the olfactory cortex, with the cerebellum, and with the striate cortex (Mizunami et al. 1997). The morphological and functional similarity between antennal glomeruli and glomeruli of ver-

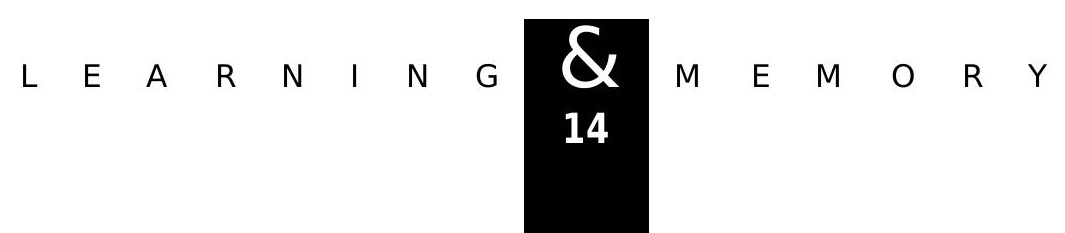


MUSHROOM BODY EVOLUTION

tebrate olfactory bulbs has been emphasized by Shepherd and Greer (1998). In mammals, the next stage of processing is in the olfactory cortex, which, like the hippocampus, is a phylogenetically ancient and conserved part of the brain. Its position in the olfactory pathway would be serially equivalent to the calyx of the insect mushroom body.

Schürmann (1974) has suggested that the sequential organization of narrow dendritic fields of output neurons across parallel arrays of Kenyon cell axons is comparable to the arrangements betw een Purkinje cells and parallel axons of granule cells in the cerebellum. Schürmann (1974) proposes that the arrangement of parallel fibers and efferent neurons could serve to detect temporal events in olfactory stimulation similar to the timer hypothesis for the cerebellum (Braitenberg 1967). Recent studies on synchronized activity in the olfactory pathw ay suggest that timing among neural assemblies plays a crucial role in odor discrimination (for review, see Laurent 1997).

Laminae in the cockroach mushroom body (see below) have been analogized with columns in mammalian striate cortex (Mizunami et al. 1997), but this comparison would be difficult to reconcile with the mode of mushroom body development. Whereas cortical columns, each with a distinct set of afferents, can be potentially established during neurogenesis (Kuljis and Rakic 1990), their maturation and final arrangements depend strongly on sensory experience (Chapman and Stryker 1992). The laminae of the cockroach mushroom bodies, however, represent annular arrangements of Kenyon cell dendrites in the calyces, which share the same afferents but increase in number at each developmental instar (Weiss 1974). Possibly, this arrangement is hard wired. Experiments that deny antennal input to the antennal glomeruli throughout post embryonic development and thereby drastically reduce the size of the antennal lobes and their connections to the calyces do not reduce the number of laminae (N.J. Strausfeld, unpubl.).

Considering that some genes control the development of comparable structures across very diverse phyla, as in the case of the role of the Pax-6 gene in eye development (Callaerts et al. 1997), there are obviously certain commonalities between arthropod and vertebrate brains. How ever, given the gross structural differences between them, the probability seems low that the mushroom bodies and certain vertebrate brain regions could be derived from the same ancestral neural netw ork and develop under the control of homologous genes.

\section{MUSHROOM BODIES IN ODOR-SENSITIVE INSECTS}

This section outlines the organization of insect mushroom bodies. These can be usefully compared with mushroom body-like neuropils in distantly related groups, such as the annelids (worms; Fig. 2A) and the cheliceriformes (e.g., solpugids, pycnogonids; see Fig. 6 , below) described in the next sections.

\section{PEDUNCULUS AND LOBES}

Insect mushroom bodies usually have two or more sets of lobes arising from the pedunculus at the front of the brain: the vertical lobe assemblage, the medial lobe assemblage, and, in some species, additional frontal or recurrent lobes (Figs. 2-4). However, Jawlowski (1959b) reports that in certain vespids (wasps) the pedunculus is undivided and does not form a vertical lobe. In Jawlowski's descriptions, the vespid pedunculus is greatly widened beneath the calyces, tapering to a small medial lobe.

Comparisons between insect groups suggest that within an order there are highly conserved features of mushroom body shape and lobe arrangements (Figs. 2-4). In Drosophila and other brachyceran Diptera (Fig. 4D), the medial and vertical lobes are bipartite, each divided into two parallel components called, respectively, $\beta, \gamma$, and $\alpha$, $\alpha^{\prime}$ (Ito et al. 1998). Kenyon cells providing an axon to the medial $\beta$ generally provide a branch into the vertical $\alpha$. Kenyon cells supplying $\gamma$ usually supply a tributary to $\alpha^{\prime}$. The segregation between the vertical $\alpha$ and $\alpha^{\prime}$ is less clear than between the medial $\beta$ and $\gamma$. In some Diptera, such as the horse fly Tabanus, divisions of the medial lobes are almost completely segregated into two entities (Fig. 4E,F). Undivided medial and vertical lobes occur in many Hymenoptera (e.g., honeybees, ichneumon wasps, ants; Jaw lowski 1959a,b, 1960; Goll 1967) and Blattodea (e.g., cockroaches; Fig. 2A). In Dermaptera (earwigs), the pedunculus and lobes are clearly divided into three parallel components that carry through the tripartite arrangement of their calycal neuropil (Fig. 2D). Coleopteran mushroom bodies (see also, Jawlowski 1936) generally appear simpler than those of many other groups. Their vertical lobes comprise a single shaft as does the medial lobe (Fig. 2E,G). But both are subtly divided into concentric longitudinal components. These struc-

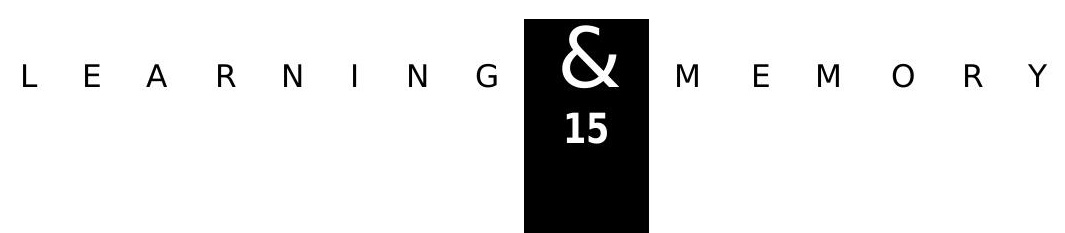


Strausfeld et al.

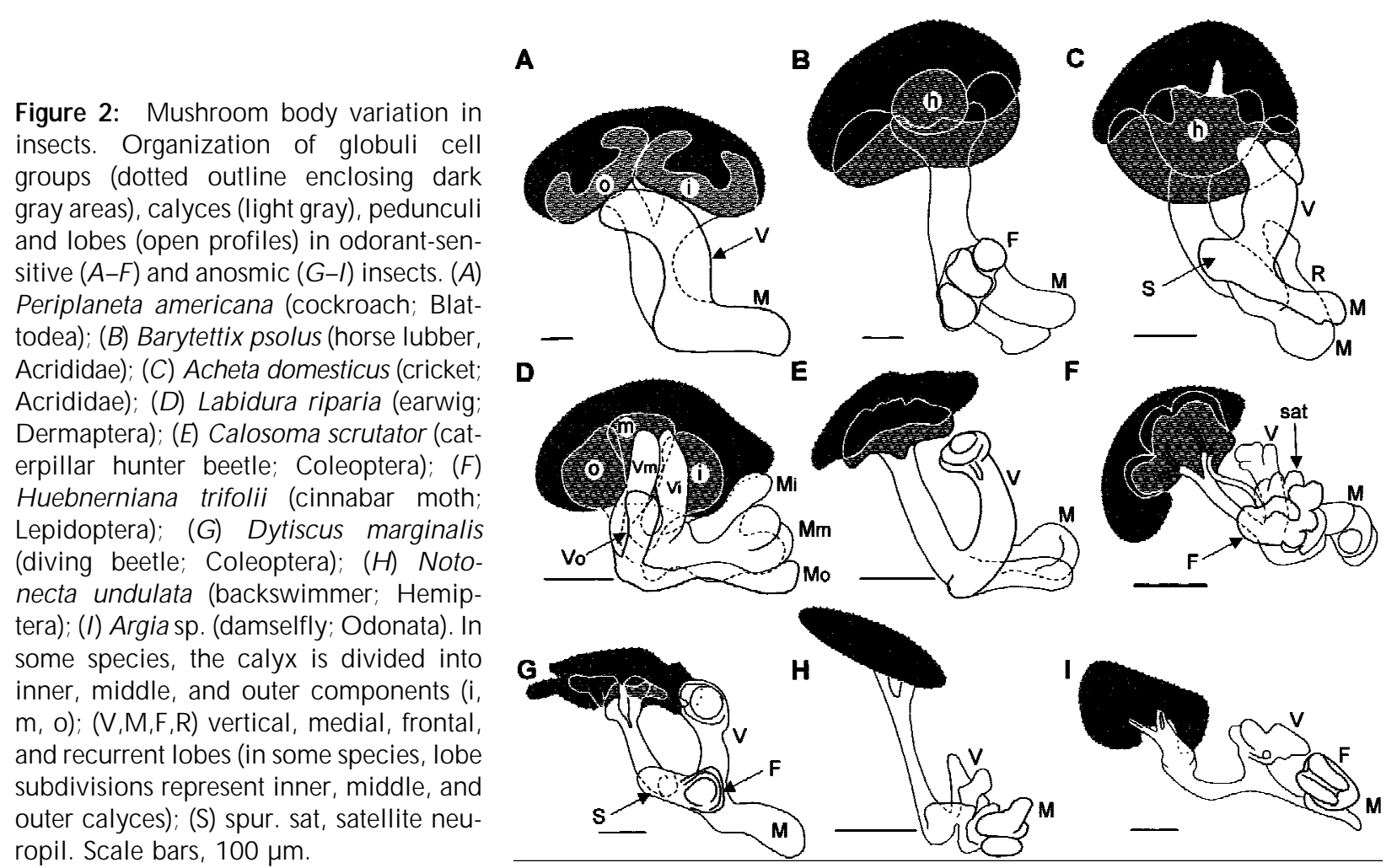

tures are all highly conserved, even between odorsensitive species with large calyces (Figs. 2E and $4 \mathrm{H}$ ) and almost anosmic species of the same order that have reduced calyces, such as diving beetles (Figs. $2 \mathrm{G}$ and $4 \mathrm{I}$ ).

The Lepidoptera provide another example of order-specific arrangements (Bretschneider 1924). Pearson's (1971) description of the hawk moth Sphinx ligustri describes a " $\gamma$ lobe," disposed parallel to the $\beta$ component of the medial lobe, that is supplied by a bundle of Kenyon cell axons projecting separately from the pedunculus. This organization has also been identified in various other lepidopterans, such as the cinnabar moth Huebneriana trifolii (Fig. 2F), the wood nymph butterfly Cercyonis pegala, and the hummingbird hawk moth Hemaris thisbe (Fig. 4C). In all three, a separate bundle of Kenyon cell axons supplies a lobe that is satellite to a complicated arrangement of medial and vertical lobes (Figs. 2F and 4C). Additional features shared by Lepidoptera are the unusually large and relatively sparse Kenyon cell bodies supplying a large cap-like calyx (Fig. 2F).

INTERNAL ARCHITECTURE OF THE PEDUNCULUS AND LOBES

A variety of internal architectures distinguish the medial and vertical lobes of different genera. Vowles (1955) noted that striations in ant mushroom bodies extend throughout the pedunculus and lobes. Goll (1967) related three concentric zones in the calyces of the ant Formica to three discrete subsets of globuli cells and to three laminae that extend through the pedunculus and lobes. Mobbs (1982) also suggested that the concentric arrangements of the lip, collar, and basal ring neuropils of the honeybee calyx were transformed into three parallel layers that extend through the pedunculus and lobes. In the Blattodea (e.g., Periplaneta americana), alternating dark and pale laminae were first identified by Bretschneider (1914) using basic staining methods and have since been confirmed by Bodian staining ( $\mathrm{Li}$ and Strausfeld 1997; Mizunami et al. 1997; Strausfeld 1998c). In Periplaneta, synaptic specializations from efferent neuron dendrites and afferent terminals coincide with alternate laminae (Fig. 5A), which themselves are continuous throughout the pedunculus and lobes (Fig. 5B,C). Laminae have also been identified in orthopteran mushroom bodies (Barytettix psolus; Acheta sp.). Immunocytology of the honeybee mushroom bodies demonstrates, how ever, many more longitudinal subdivisions than originally suggested by Mobbs (1982, 1984). Antibodies 


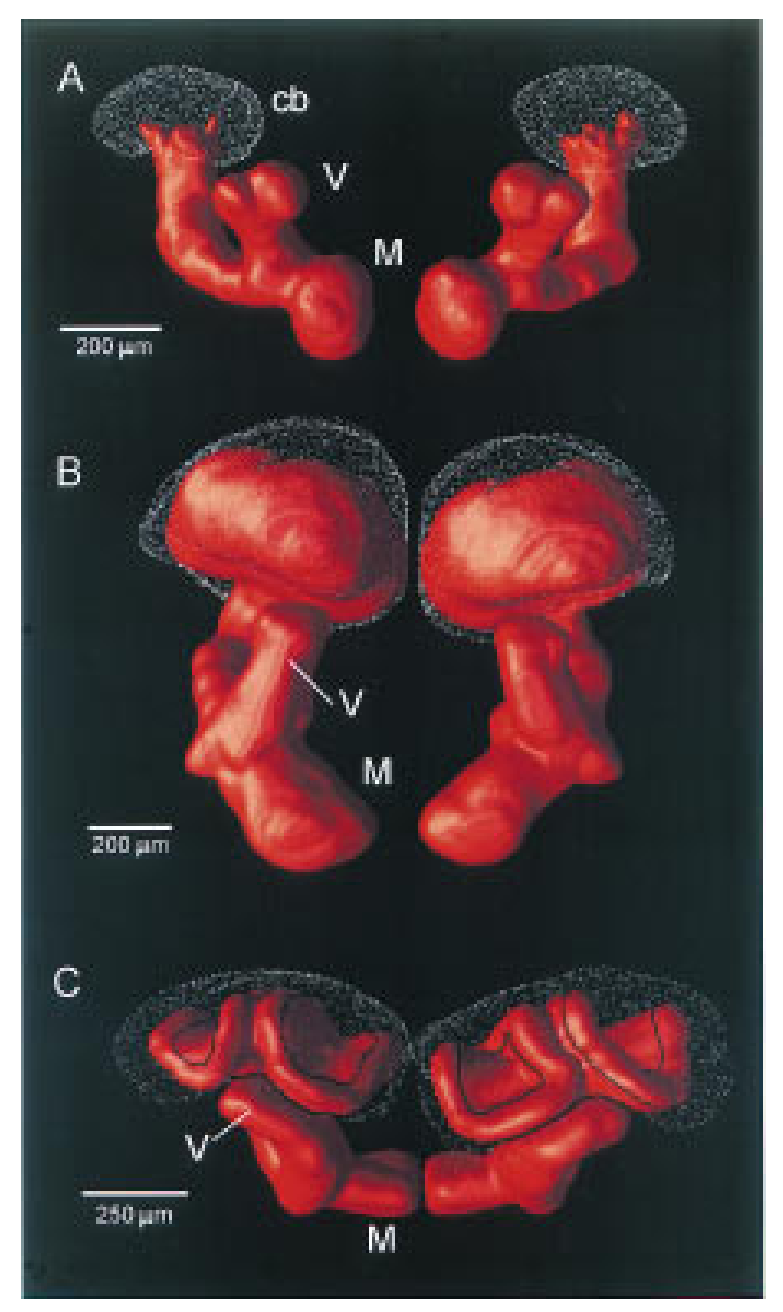

Figure 3: Surface-tessellated reconstructions of mushroom bodies. (A) Primitive calyxless condition in the silverfish Lepisma. (B) Single calyx in Schistocerca (locust). ( $C$ ) Double calyces of the honeybee, Apis mellifera. (cb) Globuli cell bodies; $(\mathrm{V}, \mathrm{M})$ vertical and medial lobes, respectively.

raised against neuropeptides exquisitely demonstrate Kenyon cell laminae. These are variously defined by the presence of taurine (Bicker 1991), FMRFamide (Schürmann and Erber 1990), and gastrin-cholecystokinin, or combinations of these (Fig. 5G; also Strausfeld 1998a,c).

Longitudinal subdivisions of the lobes suggest that in many species mushroom bodies may comprise several parallel and isolated networks that may support different computational functions (Strausfeld 1998a). Therefore, it is significant that efferent neurons are not themselves responsible for the lamination within the mushroom body lobes. Instead, their branches are restricted within specific pre-existing laminae (Fig. 5A,E,F). Each efferent arborization occupies only a short distance of the length of the lobe and the patterning of dendritic arborizations from successive efferent neurons changes from one position to the next along the lobes. If extrinsic neurons would substantially contribute to one or another lamina, as has been suggested (Rybak and Menzel 1993), then many identical dendritic trees would be required to provide an isomorphic structure (lamina) extending from the calyces to the distal ends of the lobes. This is not the case.

A number of insect orders show columnar or concentric subdivisions through the pedunculus and lobes, as in the blow fly Calliphora, in which antibodies against a GABA receptor protein reveal four columns in the pedunculus (Brotz et al. 1997). Staining for nitric oxide synthase has revealed a quadripartite arrangement of columns through the locust's vertical lobes (Elphick et al. 1995). Products of gene expression also show discrete subdivisions throughout the lobes of Drosophila that can be ascribed to different populations of Kenyon cells (Yang et al. 1995; Ito et al. 1997). Judging from all these studies (with the possible exception of that by Elphick et al. 1995), it is most likely that Kenyon cells are responsible for all of these longitudinal divisions. Direct confirmation has been obtained by retrograde dye injection into laminae of cockroach mushroom bodies revealing them to be derived from an annular arrangement of Kenyon cell dendrites in the calyces (N.J. Strausfeld, L. Hansen, and $Y .-S$. Li, unpubl.).

Do the different types of parallel subdivisions among Kenyon cells share a common organizational plan? In other words, can the relatively simple subdivisions among Kenyon cells in Drosophila, for example (Yang et al. 1995), be reconciled with the isomorphic laminar arrangements of Kenyon cell axons in the cockroach and can this arrangement, in turn, be reconciled with the unequal laminations observed in the honeybee lobes? A possible answer is suggested by comparisons betw een hemimetabolic insects that develop through several instars, each providing an immature version of the adult, and holometabolic insects that undergo a more or less complete metamorphosis from larva to adult through postembryonic pupal development.

In the cockroach, which is a hemimetabole, the adult mushroom body possesses between 24 and 30 laminae, alternating as pale and darker structures (Fig. $5 \mathrm{C}$ ) and reflecting the successive 
Strausfeld et al.

grow th of annular arrangements of Kenyon cells in the calyx (Weiss 1974). An intriguing aspect about this lamination is that first-instar Periplaneta mushroom bodies have only two longitudinal divisions and their medial lobes look remarkably similar to those of adult Drosophila and other Diptera (e.g., Tabanus, Sarcophaga; Fig. 4D-F). The mushroom bodies of a third- to fourth-instar cockroach nymph (Fig. $5 \mathrm{H}$ ) possess only eight laminae of unequal width, which, together, look like the arrangement of laminae in the adult honeybee (Fig. 5F,G). Thus, early stages of the hemimetabolous mushroom bodies appear to be representative of mushroom bodies of adult holometabolous insects. This observation raises the possibility that mushroom bodies in the Holometabola are, to various degrees, neotenic: the mushroom body in one species being similar to an evolutionarily basal cockroach mushroom body at a specific stage of its development.

In addition to longitudinal subdivisions, there

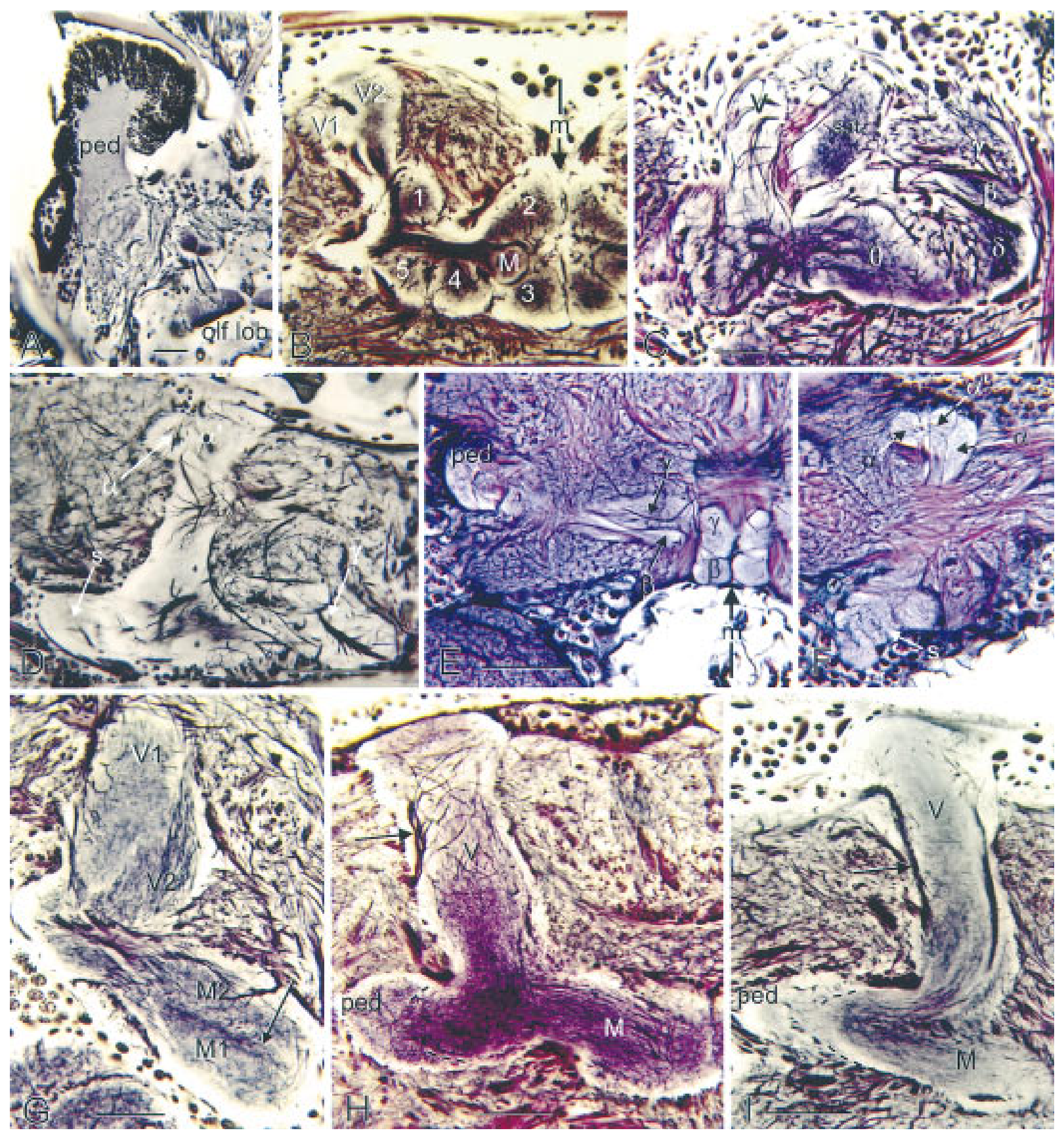

Figure 4: $\quad$ (See facing page for legend.)

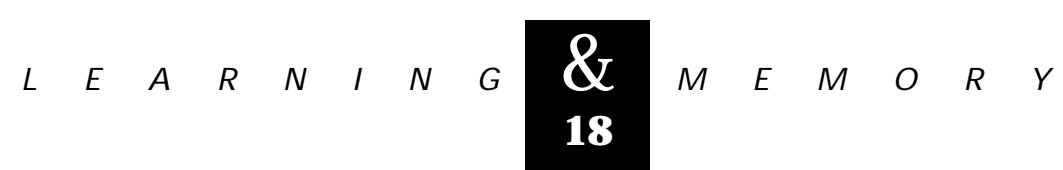


are also obvious transverse divisions across the lobes defined by segment-like arrangements of dendrites belonging to efferent neurons (Fig. 5D; see also Li and Strausfeld 1997) and terminal domains of certain afferents that reach the lobes from other brain areas (Li and Strausfeld 1997, and unpubl.). Histochemical staining with the Falck-Hillarp method also reveals segmentation across Kenyon cell axons (Frontali and Norberg 1966; Frontali and Mancini 1970; Schürmann and Klemm 1973; Klemm 1983) suggesting that certain afferents to the lobes are rich in catecholamines.

\section{CALYCES}

In all insects, Kenyon cells originate from clusters of cell bodies (globuli cells) over the dorsal anterior surface of the lateral protocerebra. Neurites (cell body fibers) of globuli cells prolongate anteriorly to give rise to the pedunculus and lobes. In insects equipped with antennal lobes, Kenyon cells provide dendrites that form a cap- or cuplike region, called the calyx, at the head of the posterior end of the pedunculus. Generally, Kenyon cell dendrites in the calyx are visited by varicose specializations from collaterals of antennal lobe projection neurons, en route to their termination area in the protocerebrum's lateral horn (Strausfeld 1976; Homberg et al. 1989; Malun et al. 1993; Ito et al. 1998).

There is considerable variation of calyx morphology in different genera (Figs. 2-4). Whereas primitive apterygotes and palaeopteran insects lack calyces (Fig. 3A), neopteran insects, such as orthopterans (grasshoppers, lubbers, crickets, Figs.
$2 \mathrm{~B}, \mathrm{C}$ and $3 \mathrm{~B}$ ) have mushroom bodies possessing a single calyx that is characteristically subdivided into a central hillock and an outer ring (Figs. 2B,C; see also Jaw low ski 1954; Weiss 1981). Other neopterans, such as the Blattodea (cockroaches), have two cuplike calyces for each mushroom body (Fig. 2A). Each calyx of a pair receives essentially identical inputs and its Kenyon cell organization and projections are indistinguishable (Weiss 1974; Strausfeld 1998a). The Hymenoptera also have two calyces for each mushroom body (Fig. 3C). These are simplest in the Symphyta (Jawlow ski 1960) in which each calyx consists of a knoblike neuropil on a short peduncular stalk that merges with the other stalk to form the pedunculus proper, as occurs in the Blattodea. Coleoptera have a pair of caplike calyces for each mushroom body (Jawlowski 1936), though in some species these are fused (Fig. 2E). In Diptera and Lepidoptera (Fig. $2 \mathrm{~F}$ ), each mushroom body might also be considered as having two calyces that are secondarily fused, each providing a short outer stalk that is supplied by two bundles of axons, the two stalks then merging to form the pedunculus. Even in anosmic neopteran species that secondarily lack calyces, globuli cells provide four strands of cell body fibers that contribute to tw o bundles that converge into a thin pedunculus (Fig. 2l).

As first described by Flögel (1878), and again show $n$ by Pflugfelder's (1937) study of the Hemiptera, the size of the calyx is often thought to be proportional to the number of antennal lobe glomeruli, although this relationship may be more difficult to assess in certain Hymenoptera in which calyx size may combinatorially reflect the size of

Figure 4: Mushroom body lobes of an annelid compared with those of insects. (A) Mushroom body of the scale worm Arctenöe vittata has its pedunculus (ped) capped by many thousands of globuli cells. Its pedunculus and single lobe receive inputs from the olfactory lobe (olf lob). (B) Apterygote Thermobia (firebrat) has a divided vertical lobe (V1, V2) and five glomerular medial lobes (1-5) flanking a smaller lobe in the middle (M). (C) Medial lobes of the hummingbird moth Hemaris thisbe are elaborately subdivided with the $\gamma$ lobe, as originally defined by Pearson (1971), lying alongside the vertical lobe $(\mathrm{V})$. Like in other Lepidoptera, the medial lobe is subdivided into many components $(\beta, \delta, \theta)$, with satellite neuropil (sat) provided by a small bundle of Kenyon cell axons (not in plane of section). (D) Medial lobe of the fleshfly Sarcophaga carnaria, like D rosophila (Ito et al. 1998), does not show obvious division into separated $\gamma$ and $\beta$ components. $(E, F)$ In the horsefly Tabanus, the medial lobes show complete terminal separation of the $\beta$ and $\gamma$ components and the vertical lobe $F$ is deeply divided into two components $\left(\alpha\right.$ and $\left.\alpha^{\prime}\right)$. The spur (s) is an outgrowth of the junction of the pedunculus with the vertical and medial lobes. In this tabanid, the spur is divided into three components. $(G)$ Vertical and medial lobes of the tettigonid Scudderia furcata, like those of many other orthopterans, show striking longitudinal zonations. A dense band of Kenyon cells (arrow) is flanked by two parallel divisions M 1, M2, corresponding to V1, V2 of the vertical lobe. $(H, I)$ Vertical $(\mathrm{V})$ and medial lobes $(\mathrm{M})$ of a predatory tiger beetle $(H$, Cicindelidae) are proportionally as large as those of the water beetle Dytiscus marginalis (I), although the latter has a greatly reduced calyx. Note the extrinsic neuron axons (arrow) leaving the distal end of the vertical lobe. The pedunculus (ped) of each is sectioned obliquely to show two parallel divisions (broken lines in $H, I)$ comprising thick and thin Kenyon cell axons. Scales in $A, G, H, I, 50$ $\mu \mathrm{m}$; scales in $B-F, 100 \mu \mathrm{m}$. The midline in $B$ and $F$ is indicated by an arrow (m).

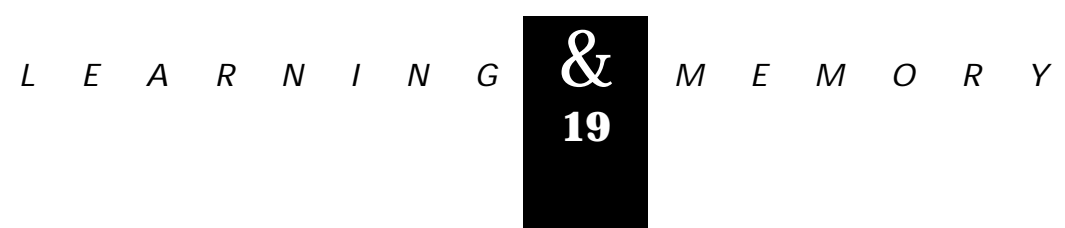


Strausfeld et al.
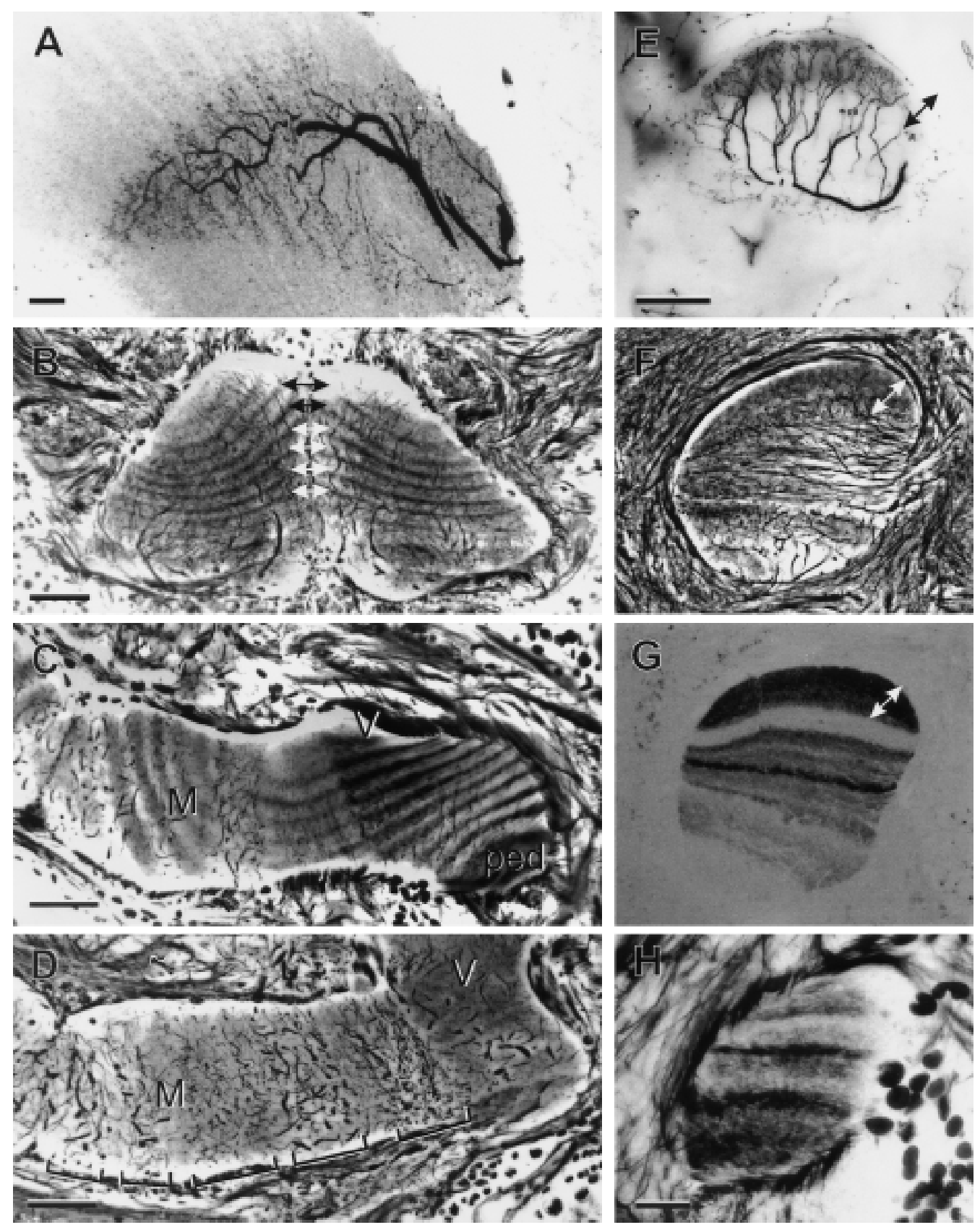

Figure 5: Internal organization of the mushroom bodies in hemi- and holometabolous insects (Periplaneta; $A-D, H$ and Apis; $E-G$ ). (A) Laminar organization of efferent neuron dendrites matches Kenyon cell laminae. (B) O blique sections through the tips of the left and right medial lobes reveal the alternating pale and dark Kenyon cell laminae, which, in any individual, are symmetrical about the midline (double arrows). $(C)$ O blique section, through the base of the pedunculus (ped), the origin of the vertical lobe (V), and the medial lobe (M) shows the unbroken continuity of Kenyon cell laminae. Profiles at right angles to the laminae belong to efferent dendrites arranged as palisades, as shown in frontal sections (bracketed in $D$ ). (E) In honeybees (A pis mellifera), processes of extrinsic neurons invade specific laminae. The equivalent levels in $E-G$ are indicated by double-headed arrows. In Apis, Kenyon cell laminae are of unequal width $(F)$ and have different affinities to antibodies raised against peptides (e.g., anti-gastrin staining, shown in $G$ ). $(H)$ Immature fourth instar pedunculus of Periplaneta showing laminae of unequal width and different staining affinities, reminiscent of the adult honeybee. Scale bars in $A, 20 \mu \mathrm{m} ; B-G, 50 \mu \mathrm{m} ; H, 10 \mu \mathrm{m}$.

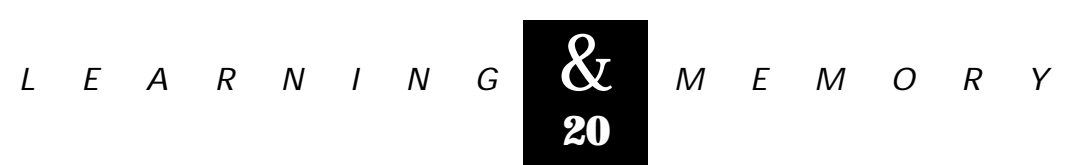


the antennal lobes, the amount of optic lobe input, the caste status, and the sex of the individual. How ever, although Dujardin suggested that the calyces of social Hymenoptera are the largest, Jawlowski (1959a) claims that certain Ichneumonidae possess the largest calyces relative to the rest of the brain's volume. In ichneumonid and aculeate Hymenoptera (e.g., honeybees), calyces comprise three (in honeybees four) concentric zones, termed I, II, III, and Illa (Jawlowski 1959b), or the lip, collar, and basal ring (III and IIIa) of Mobbs (1982). Olfactory afferents supply zones I and III (Mobbs 1982, 1984), whereas projections from the medulla and lobula of the optic lobe invade zone II (Jawlowski 1958; Gronenberg 1986, 1998). Massive convergence in the calyces of tw o modalities from peripheral sensory neuropils is, however, unusual. In other insect orders, calyces have meager, if any, afferents from the optic lobes and instead serve as a specialized distal region of the mushroom bodies associated with olfactory inputs from the antennal lobes. As will be discussed later, the lobes also receive major afferent supply.

\section{MUSHROOM BODIES IN ANOSMIC INSECTS}

In secondarily anosmic insects, such as the diving beetle Dytiscus, the back-swimmer Notonecta undulata, and cicadas, antennae are sometimes greatly reduced or may serve mechanosensory functions exclusively (as in Notonecta; Rabe 1953). Such species lack antennal lobes. They also either lack calyces (cicadas, Notonecta; Fig. $2 \mathrm{H}$ ) or the calyces are greatly reduced (as in Dytiscus; Fig. 2G) compared with an odor-sensitive species of the same order (e.g., the caterpillar hunter beetle, Calosoma scrutator; Fig. 2E). In such calyxless species, thin cell body fibers from the globuli cells form a narrow pedunculus that increases in diameter anteriorly only where it provides the lobes. Because there are no Kenyon cell dendrites distally, as there are in the calyces of odor-detecting species (see below), Kenyon cells can only contribute to local circuits in the lobes between afferent neurons supplying the lobes and efferent neurons leaving them.

\section{MUSHROOM BODY-LIKE STRUCTURES \\ IN CHELICERIFORMES}

The relationship betw een mushroom body-like structures and first order olfactory neuropils is exquisitely shown in the Cheliceriformes.
All Cheliceriformes possess mushroom bodylike neuropils within the anterior neuromere (protocerebrum) of the supraoesophageal (prosomal) ganglion. Chelicerate mushroom bodies accord with Flögel's and Kenyon's criteria for mushroom bodies of insects. They comprise many hundreds, or in some species, hundreds of thousands, of parallel fibers that originate from dorsal clusters of basophilic globuli cells. Golgi impregnations demonstrate that parallel fibers give rise to dendrites either proximate to the globuli cell clusters, or they give rise to groups of dendrites at specific positions along the lengths of the lobes. Except in the case of araneans (spiders), in which mushroom body-like centers are visual neuropils (Strausfeld and Barth 1993), Kenyon cells are supplied by afferents that relay from olfactory glomeruli. The latter are not situated within the chelicerate brain. No arthropod interpreted as a chelicerate (including the Mid-Cambrian species Sanctacaris; Briggs and Collins 1988) possesses antennae. Instead, olfactory glomeruli are situated in segmental neuromeres associated with olfactory appendages that arise from body (opisthosomal) segments.

The cheliceriform mushroom bodies can reach varying degrees of elaboration. In scorpions, mushroom bodies are relatively small, being supplied by a few thousand globuli cells (in Centruroides sculpturatus). In the amblypygids, or whip-spiders (amblypygids are not true spiders), the lobes are huge, richly convoluted (Babu, cited on p. 1256 of Bullock and Horridge 1965), and are supplied by two pairs of globuli cell clusters $(\sim 300,000$ neurons in Tarantula $s p$ ) that form a roof over the protocerebrum. Limulus polyphemus possesses some millions of globuli cells (Viallanes 1893; Fahrenbach 1979), which give rise to neurons that bear close resemblance to insect Kenyon cells except that their axons are described as relatively short. (Fahrenbach 1979). Our own studies suggest that some axons extend either side of the oesophagus to form lobes that extend posteriorly and medially tow ard ventral neuromeres where they are possibly confluent with tracts of ascending axons of segmental olfactory interneurons. Limulus mushroom body afferents (assumed to be olfactory projection neuron endings) that reach Kenyon cell dendrites are described (see Fig. 15, in Fahrenbach 1979).

In different chelicerate orders, olfactory glomeruli are associated either with specialized abdominal (metasomal) appendages, modified walking limbs of the thorax (mesosoma) or, in one case,

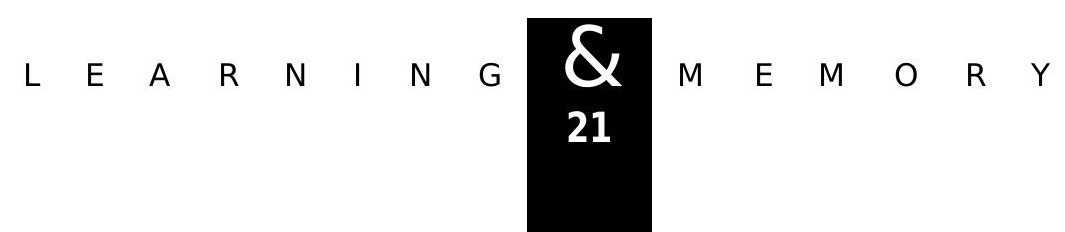


Strausfeld et al.

with the palps. For example, in scorpions, a pair of chemosensory organs (called pectines; Gaffin and Brownell 1997) extends from the first abdominal segment. Pectines send their chemosensory axons into a small cluster of large olfactory glomeruli situated in the first metasomal and in the last mesosomal neuromere. Yet, in scorpions as in all chelicerates, the mushroom bodies are situated within the protocerebrum, receiving relays from olfactory glomeruli via tracts that carry ascending axons of projection neurons.

The typical relationships between the size of chelicerate mushroom bodies and the number of olfactory glomeruli is shown in Figure 6 . In solpugids (sun spiders but, again, not true spiders), specialized chemoreceptor organs called malleoli (Brownell and Farley 1974) extend from the last leg pair. The enlarged palps of solpugids are also specialized as olfactory receptor organs and demonstrate an interesting example of evolutionary convergence: the modification of anterior appendages to antenna-like structures (Fig. 6A). In solpugids, olfactory glomeruli are situated medially in the first and second mesosomal ganglia, in which they receive ascending receptor axons from the malleoli and receptor axons from the palps (Fig. $6 \mathrm{~B})$. In uropygids (vinegaroons) and amblypygids (whip spiders; Fig. 6C), it is the first leg pair that has evolved into an antennoform chemoreceptor organ, again providing a wonderful example of convergent evolution of a frontal antenna. The first leg pair is grotesquely elongated in the amblypygids in which the first, second, and third mesosomal ganglia are packed with small olfactory glomeruli that anteriorly invade cephalic (prosomal) neuromeres (Fig. 6D). The amblypygid mushroom body lobes are so large and so convoluted that they appear to have miniaturized other brain neuropils. Reconstructions of these mushroom bodies show gyri and folds that are reminiscent of the gyri seen in some mammalian cortices (Fig. 6D). In solpugids, which have relatively few olfactory glomeruli, the mushroom bodies are about one-fiftieth of the size of those of amblypygids (Fig. 6B).

The most basal organization of the cheliceriform olfactory pathway is in the Pycnogonidae (Fig. 6E,F), in which each leg supplies a group of a few glomeruli that are associated with intersegmental pathways ascending to a small mushroom body in the brain. Several morphological features suggest the primitive nature of this system. Metameric thoracic ganglia are unfused, a condition seen in no other cheliceriform; the olfactory sen-
A
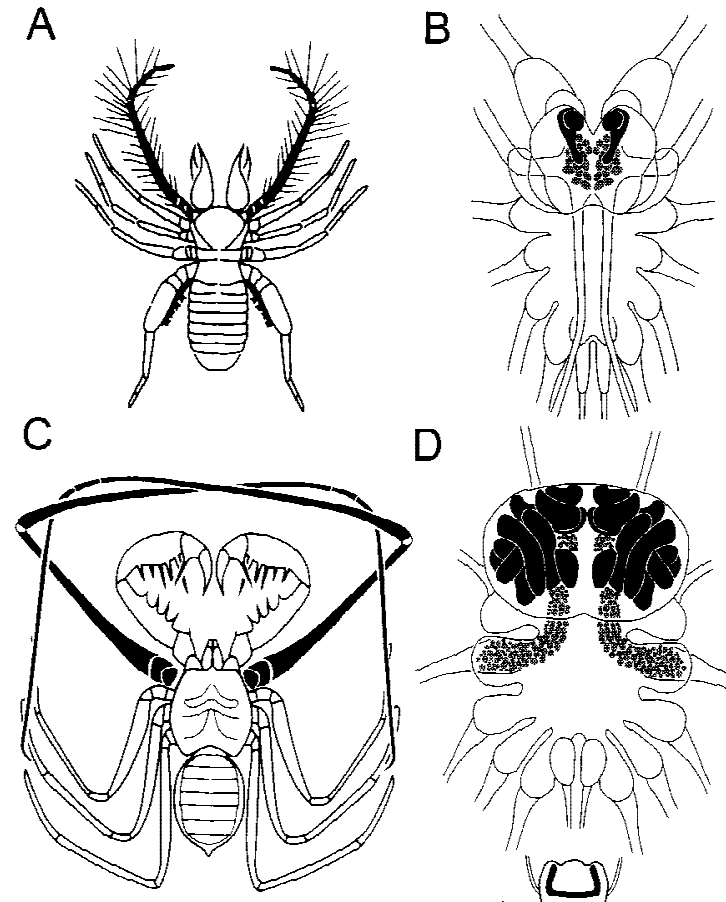

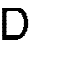

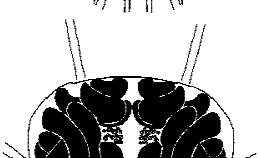

$E$

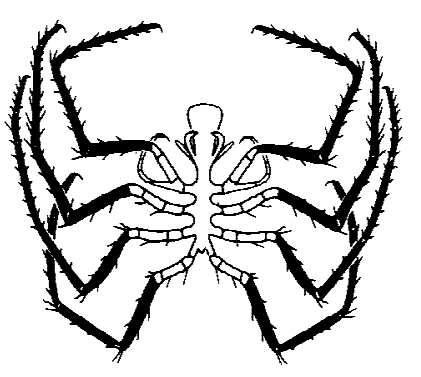

$\mathbf{F}$

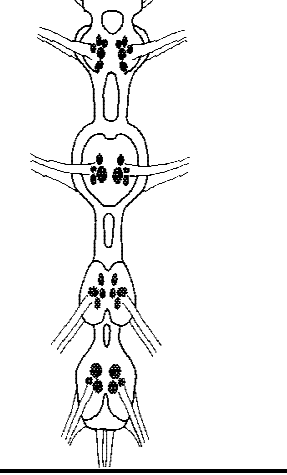

Figure 6: Chelicerate mushroom bodies showing the relationship between glomeruli number and mushroom body size and elaboration. O Ifactory receptor organs are shown in black in the solpugid Eremboates pallipes $(A)$, the amblypygid Tarantula sp. $(C)$, and the pycnogonid Lecythorhyncus hilgendorfii (E). Irrespective of the location of glomeruli, mushroom bodies (solid black profiles, $B, D, F)$ are located within the protocerebrum. In solpugids $(B)$, malleoli provide afferents to glomeruli (shaded in $B, D, F$ ) in the first and second opisthosomal (postoral) ganglion. In amblypygids $(D)$, a grotesquely elongated first leg pair supplies afferents to hundreds of small glomeruli in the first opisthosomal ganglion that spread into supraoesophageal neuropil. In pycnogonids $(F)$, glomeruli are arranged segmentally in ganglia associated with the legs. In this class of Cheliceriformes, the left and right mushroom body lobes are confluent at the protocerebrum's midline.

sillae repeat on each segmental appendage; and the mushroom body lobes, like those of onychopho- 
rans and diplopods (Holmgren 1916; Schürmann 1995; Strausfeld et al. 1995), are confluent across the midline.

\section{MUSHROOM BODY -LIKE STRUCTURES IN OTHER SEGMENTED INVERTEBRATES}

Neuroanatomical evidence suggests that mushroom bodies in chelicerates are second-order neuropils of the olfactory pathway. The same seems to be true of annelids, onychophorans, centipedes, and millipedes, all of which have specialized olfactory cerebral appendages. Comparisons between these different groups also show that olfactory glomeruli are associated with the mushroom bodies (Strausfeld et al. 1995). For example, in the predatory and highly territorial scale worm Arctenöe vittata, olfactory glomeruli are associated with enormous mushroom bodies (Fig. 4A). In the errant polychaete Nereis vexillosa, olfactory receptor endings terminate as small glomeruli near the head of the mushroom body pedunculus, in which they appear to be grasped by dendrites of globuli cells. In the onychophoran Euperipatoides rowellii, receptors from the olfactory appendages (tentacles) terminate in olfactory glomeruli, which are themselves a contiguous outgrow th of the mushroom bodies (Holmgren 1916; Schürmann 1995; Strausfeld et al. 1995). In diplopods (millipedes), the antennae supply receptor axons to a glomerular antennal lobe that apposes the head of the mushroom bodies. In chilopods (centipedes), there are prominent antennal (olfactory) glomeruli in the subesophageal ganglion from which ascending fibers reach the mushroom body pedunculus and lobes (Strausfeld et al. 1995).

In diplopods and onychophorans, the mushroom body pedunculus divides into several parallel medial lobes. In both orders, medial lobes fuse with their contralateral counterparts at the midline as they do in pycnogonids. In centipedes (Chilopoda), the medial lobes are lateralized and do not fuse at the midline but divide into sw ellings reminiscent of the swellings at the head of the $\gamma$ lobes in Drosophila. There is no obvious calyx, how ever, in any of the above groups (Holmgren 1916; Strausfeld et al. 1995).

Crustaceans are the only group in which mushroom bodies, structurally defined according to Flögel and Kenyon's criteria, have not yet been resolved. In decapod crustaceans (e.g., shrimps, crabs), olfactory glomeruli are supplied by the antennules (the main olfactory receptor organs). Sec- ond-order interneurons with dendrites in the (olfactory) antennule lobes give rise to bifurcating axons whose two tributaries project out into the eyestalks via a pair of tracts reminiscent of the inner antennocerebral tract of insects except that, in insects, axons linking olfactory glomeruli to protocerebral neuropils are strictly homolateral. In most decapod crustaceans, the tracts terminate in a dense neuropil, called the hemiellipsoid body, situated just proximal to the optic lobes (Mellon et al. 1992). Although Hanström (1928; see also, Nässel and Elofsson 1987; Strausfeld et al. 1995) believed that the hemiellipsoid body is homologous to the mushroom body (Fig. 1, bottom), hemiellipsoid bodies neither provide a lobed structure nor parallel fibers. Instead, the neuropils are usually arranged as strata. How ever, like the mushroom bodies, hemiellipsoid bodies are associated with thousands of minute basophilic cell bodies. The hemiellipsoid bodies might be more easily compared with mushroom bodies in decapods such as the burrowing shrimp Callianassa californienses in which the eyestalks are reduced or absent and the hemiellipsoid bodies are incorporated into the midbrain proper. However, even in this species, the hemiellipsoid bodies do not provide parallel fibers but, instead, are compact glomerular neuropils (Strausfeld 1998b).

One group of decapods lacks any neuropil even vaguely reminiscent of a mushroom body or a hemiellipsoid body. This group is the isopods (sow bugs, sea slaters, pill bugs) whose antennules supply large glomerular neuropils that are similar in appearance to the antennal lobes of flies. Yet isopods entirely lack obvious higher order olfactory neuropils, including the accessory lobes, which, in the brains of many other decapods, are glomerular neuropils in the midbrain linked to the antennule lobes (Sandeman et al. 1993). Nevertheless, isopods are a remarkably successful group, occupying habitats ranging from Antarctic Ocean to Saharan Desert. Despite their lack of mushroom bodies or possible analogues, isopods can learn olfactory cues and use olfactory communication for kin recognition and maintaining territory (Linsenmair 1987).

\section{EVOLUTION OF ARTHROPOD MUSHROOM BODIES}

The phylogenetic affinities among insects and other arthropods is still much debated, with sometimes conflicting results derived from sequence analysis of rRNA (Ballard et al. 1992) and DNA

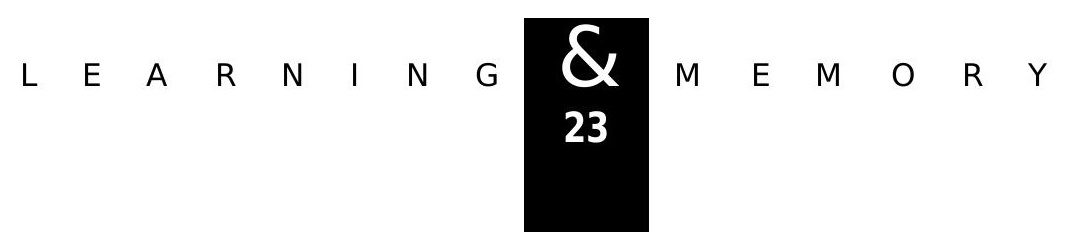


Strausfeld et al.

(Wheeler et al. 1993). In contrast, the classic approach of Holmgren (1916) and Hanström (1926), which relied on comparative anatomy of brain centers to reconstruct evolutionary relationships, suggests today that invariant cerebral architectures could be as useful in reconstructing relational trees as are other highly conserved pheno- or genotypic features.

A recent study (Strausfeld 1998b) reconstructs arthropod phylogenies on the basis of the presence or absence of 100 brain characters in 26 taxa, by use of computational tools designed for investigating closest affinities among taxa according to the degree to which they share derived characters (Hennig 1966; Sw offord 1992). Raw data for the neural analysis (Strausfeld 1998b) treats any character as wholly independent of any other. There are no conditional characters (e.g., antennal lobes, and then calyces). Thus, globuli cells are scored as present or absent independent of the presence or absence of parallel fibers. This eliminates assumptions about synapomorphy and, hence, tautology. Mutually exclusive character states are scored as present or absent and characters are treated as unordered and unweighted. The resulting tree (Strausfeld 1998b) places Onychophora basal to the Arthropoda (see also Budd 1996) with Diplopoda as a sister group, closer to them than to the Chilopoda (centipedes). Crustaceans and insects emerge as sister clades, agreeing with recent $18 \mathrm{~s}$ RNA sequence analysis (e.g., Ballard et al. 1992; Friedrich and Tautz 1995) and developmental studies (Whitington et al. 1991).

The occurrence of characters within the neural tree has been traced by use of MacClade (Maddison and Maddison 1992). Characters treated as independent entities, but that nevertheless appear to originate together and that apparently contribute to a defined neuropil, probably have mutual functional relevance, as is the case for architectural entities that, in insects, together comprise the central complex (Strausfeld 1998b). Character tracing (Fig. 7) reveals the deep occurrence of a character assemblage comprising globuli cells, parallel fibers, and lobed neuropils, all of which are precisely those features identified originally by Flögel and Kenyon to characterize insect mushroom bodies. These features are plesiomorphic to millipedes, onychophorans, and annelids as well as to chilopods and chelicerates. A derived loss of globuli cells, parallel fibers, and lobes (at event 13, Fig. 7) is proposed to account for their absence in the stem group leading to the branchiopod crusta- ceans and basal insects (archaeognathans; Labandeira and Beal 1990), both of which are hypothesized, on the basis of shared features of their visual neuropils, to derive from a common ancestor (Strausfeld 1998b). Globuli cells, and parallel fibers organized as lobes, reappear again in basal apterygotes and palaeopterans. Globuli cells occur again in the malacostracan Crustacea concomittant with the first appearance of hemiellipsoid bodies. These deduced events (Fig. 7) can be compared with the occurrence and segmental locations in the chelicerate assemblage of glomeruli and head appendages, and the occurrence among the Insecta of antennal glomeruli and calyces (see also Fig. 6).

The absence of mushroom bodies in Crustacea, but their apparent reappearance in the insects, suggests at least two possible evolutionary scenarios.

1. Mushroom body-like structures arose only once and have been highly modified as hemiellipsoid bodies in the malacostracan Crustacea (Hanström 1928) because of transformational homology (Patterson 1982). This would imply that genes for globuli cells and parallel fibers were never lost from the genome, but that a developmental pathway leading to the formation of mushroom bodies was transformationally suppressed with subsequent reversion to the original (and hence plesiomorphic) structure in insects and the appearance of a characteristically different architecture in crustaceans

2. Mushroom bodies in different groups are homoplastic and have independently evolved several times to serve a variety of sensory functions: in polyclad Platyhelminthes, in the annelid-onychophoran-diplopod-chelicerate-chilopod assemblage, and in insects subsequent to the archaeognathans.

There are two problems with the first scenario. First, mushroom bodies may have been lost prior to the emergence of the first crustaceans, in which case stem taxa of the crustacean/insect assemblage would have lacked mushroom bodies. This seems quite well supported by comparisons between the archaeognathan Machilis, possibly representing the most primitive insects (Labandeira et al. 1988), and the basal branchiopod crustacean Triops. Preliminary observations of these genera show their brains lack mushroom bodies (and globuli cells) or any other structure that could

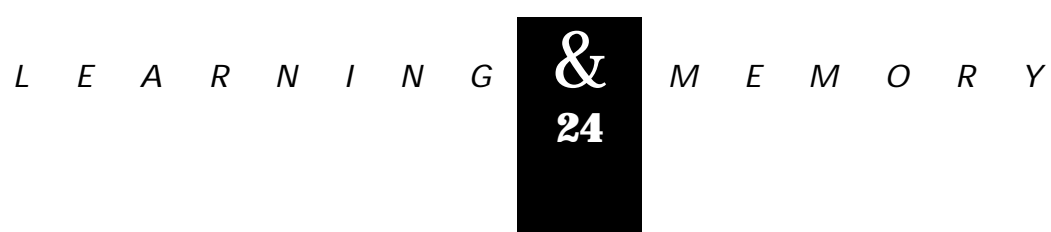




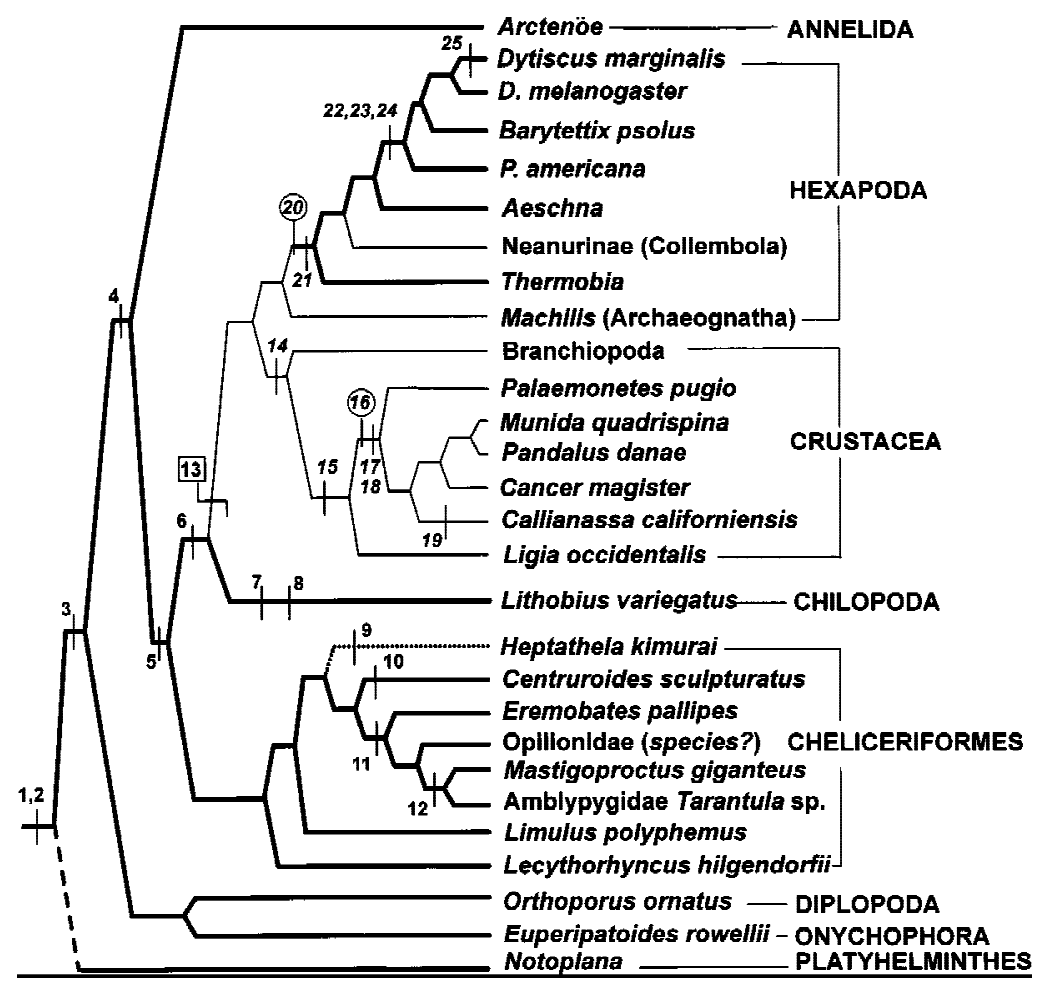

Figure 7: Strict parsimony tree, derived from an analysis of 100 neural characters and 26 taxa. (outgroups omitted; see Strausfeld 1998b). The tree widely separates chilopods from diplopods (often combined in other trees as a group called the M yriapods). Diplopods emerge as sister to the Onychophorans. Pycnogonids (L. hilgendorfii) are unambiguously placed into the clade Cheliceriformes. Platyhelminthes here shown basal to coelomates. Nonmalacostracan crustaceans (branchiopods) are more closely related to archaeognath insects than to any arthropod group, making insects and crustaceans sister groups (Strausfeld 1998b). Taxa possessing mushroom bodies, as defined by the Flögel-Kenyon criteria, are connected by heavy lines. Crustacea, the basal archaeognathan insects, and the Collembola stand apart (see text). Character mapping: (1) Globuli cells; (2) discrete lobes comprising parallel fibers; (3) chemosensory afferents ending in glomeruli; (4) lateralization of lobes; (5) metameric repetition of glomeruli; (6) postoral appendage (the antenna; secondarily preoral in crustaceans; Brusca and Brusca 1990); (7) postoral appendage chemosensory; (8) segmental glomeruli retained in first postoral ganglion; (9) glomeruli lost in all ganglia; (10) glomeruli retained in first abdominal/last thoracic neuromere; (11) glomeruli retained in first two postoral ganglia; (12) glomeruli retained in second postoral neuromere; (13) loss of characters 1-5; (14) preoral appendage (antennule); (15) wedge-shaped glomeruli; (16) homoplastic origin (re-expression?) of globuli cells; (17) dense, layered, nonretinotopic neuropil in eye stalk (hemiellipsoid body); (18) second glomerular neuropil (termed accessory lobe); (19) hemiellipsoid body in midbrain; (20) homoplastic re-expression of globuli cells; (21) parallel fibers comprising bilateral lobed neuropils; (22) antennae acquire olactor receptors; (23) glomerular neuropil supplied by antenna; (24) calyces; (25) absence of features 22-24. Characters 8-11 show a general trend for the reduction of segmental glomeruli (but these basal characters are retained in Limulus and pycnogonids). Character assemblages 1 with 2, and 20 with 21, accord with the Flögel-Kenyon criteria for mushroom bodies. Mushroom bodies, sensu Flögel-Kenyon, are shared by the annelid-onychophoran-diplopod-cheliceriform-chilopod (AODCC) assemblage but are absent in crustaceans and archaeognathan insects. Their reappearance in thysanuran insects suggests homoplasy and convergent evolution with the AO D CC assemblage. The character assemblage 22, 23, 24 is unique to neopteran insects. The character assemblage 14-18 is unique to malacostracan crustaceans. Boxed character (event) 13 presumes character loss. Circled characters $(16,20)$ indicate two possible homoplastic origins of globuli cells.

be interpreted as possibly homologous to them (N.J. Strausfeld, unpubl.). Second, if mushroom bodies are plesiomorphic, then one might expect that crustacean stem taxa (e.g., cephalocarids; Brusca and Brusca 1990) should possess mushroom bodies as defined by Flögel and Kenyon. Extremely tenuous support for this could be suggested from studies on the cephalocarid Hutchisoniella macrocantha, which Elofsson and Hessler (1990) describe from gross morphology and electron microscopy as possessing a mushroom body. However, their figures are difficult to interpret as they show only either surface features of the brain or high-resolution electron micrographs. Neither adequately resolves neural architectures and, hence, there is no clear definition of a mushroom body in this species.

If mushroom body-like structures in various taxa are the product of convergent evolution, this then raises the question of whether mushroom bodies are analogous only with respect to their morphology or whether they are analogous biochemically and functionally. This line of inquiry would strengthen the rationale for performing comparative molecular biology, such as generating cDNA libraries from globuli cells of various arthropod species with the aim of identifying mushroom body-specific proteins and thence homologous se-

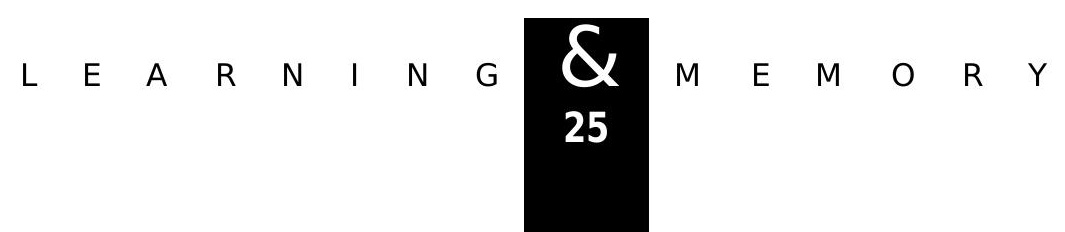


Strausfeld et al.

quences in different taxa. Such an analysis would also allow a search for possible mushroom body analogs in species with few structural similarities, such as in chordates.

An ancient origin of mushroom body-like structures is supported by morphological similarities between modern scale worms such as Arctenöe, which possesses large mushroom bodies (Fig. 4A), and Mid-Cambrian annelids, such as Canadia spinosa (Conway Morris 1979). The same comparison can be made between the external morphology of extant onychophorans, which also possess mushroom bodies, and the morphology of Mid-Cambrian Onychophora, such as Aysheaia (Whittington 1978).

Further studies on cephalocarids and on branchiopod Crustacea are urgently needed to fill gaps where there is not enough data for character analysis. So too, are comparative studies of other terrestrial hexapods (Collembola, Protura, Diplura) as these may indicate whether mushroom bodies, as defined, are homoplastic among the hexapods. For example, neanurinid Collembola (which are parainsects) do not appear to have mushroom bodies, yet they possess an insect-like central complex (N.J. Strausfeld, unpubl.).

Comparison between geologically distant genera would also be important to determine whether species within the same group, but separated by geological time, have evolved at similar rates. For example, amblypygids from West Africa and Eastern America should not have a common ancestor more recent than when the continents split apart. Do their mushroom bodies share the same characteristic elaboration of the lobes, for example, or have they diverged by some measurable set of characters? And, studies of linked characters will be useful because they may suggest emergent mushroom body functions among insect groups in which the calyces are secondarily reduced or absent.

\section{EARLIEST INSECT MUSHROOM BODIES DID NOT SERVE OLFACTION}

The evolutionary history of the mushroom bodies within the Insecta suggests that these centers did not originate as olfactory neuropils (Fig. 7). Of crucial significance are the mushroom bodies of palaeopteran insects, such as the Ephemoptera and Odonata, (mayflies, dragonflies, damselflies), as well as primitive apterygotes such as the Thysanura. The fossil record suggests that these are the earliest orders for which extant representatives still exist (Labandeira and Sepkoski 1993) and that they arose some 100 million years before the advent of neopteran taxa, such as the Blattodea, whose modern representatives possess antennal lobes and calyces.

Thysanura, Ephemoptera, and Odonata are probably all primarily anosmic with respect to airborne odors. This conclusion derives from neuroanatomical studies that demonstrate that in Thermobia and Lepisma (firebrat, silverfish) the antennae supply a mechanosensory neuropil the architecture of which is almost identical to striate mechanosensory neuropil of crustacean brains, which also receives afferents from the antennae (Strausfeld 1998b). A crucial feature is that these apterygotes, as well as palaeopteran insects, all lack the glomerular antennal lobes typical of Neoptera whose ancestors first appeared in the Late Carboniferous. Another important feature of the mushroom bodies of primitive anosmic insects is that they lack calyces. However, their neuropils derive from thousands (in odonates, hundreds of thousands) of globuli cells that provide cell body fibers forming a thin pedunculus, which, anteriorly, gives rise to elaborately subdivided and swollen lobes (Figs. $2 \mathrm{I}$ and 4B).

Judging from their modern representatives, the mushroom body lobes of these earliest insects thus seem to serve mainly mechano- and optosensory integration rather than olfaction. Nevertheless, it is important to note that this evolutionary legacy has been maintained in neopteran species that are sensitive to odors and that it is crucial to our understanding of how mushroom bodies w ork. In Periplaneta, for example, which by most accounts represents an evolutionarily basal species (Kukalová-Peck 1991; Kambhampati 1996), as well as in orthopterans and in the more recently evolved brachyceran Diptera (e.g., Drosophila; see MacAlpine 1989), mushroom bodies receive afferents to their medial lobes in addition to the olfactory supply to their calyces (Schürmann 1970a,b, 1971; Li and Strausfeld 1997; Ito et al. 1998). Afferents have also been identified in the vertical lobes of Apis (Strausfeld 1998a). Intracellular recordings from Periplaneta demonstrate that afferents to the lobes carry multimodal information (Fig. 8A). If this is a general feature across taxa, then it would account for the range of modalities that can be recorded from efferent neurons carrying information from the orthopteran and blattoid mushroom bodies to other areas of the protocere- 


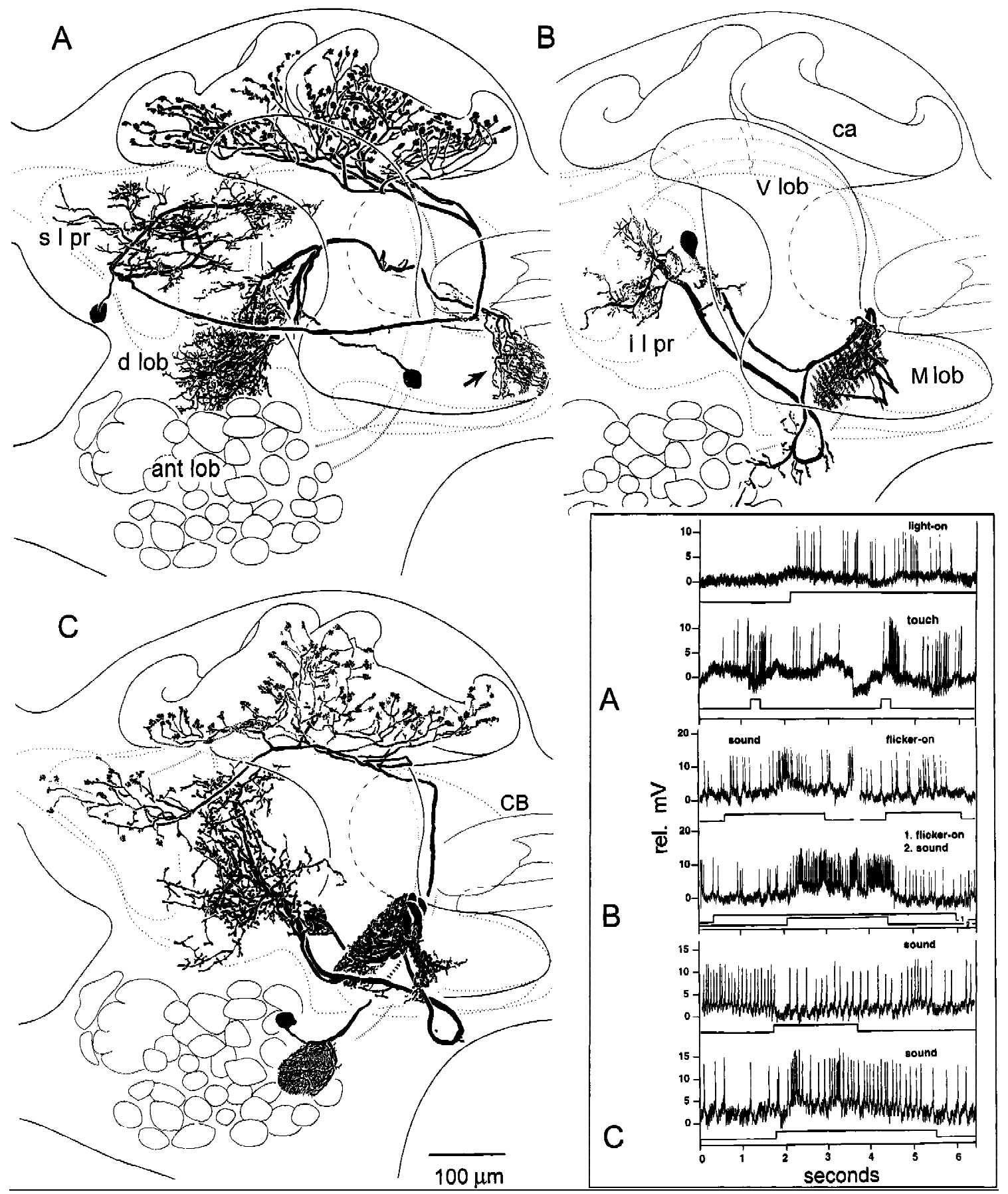

Figure 8: Multimodal and context-modified responses in the efferent neurons of Periplaneta mushroom bodies relate to afferent identities. $(A)$ In addition to their supply from the antennal lobes (ant lob; shown in $C$ ), the calyces (ca) are supplied by afferent neurons originating in superior lateral protocerebrum (s I pr) and responding to nonolfactory modalities (visual and tactile; top traces, inset $A$ ). Another afferent is shown originating in the dorsal lobes (d lob) and terminating at the tip of the medial lobe (arrow). (B) Combinations are more effective than unimodal stimuli in eliciting a response from this efferent neuron linking the medial lobe to the inferior lateral protocerebrum (i I pr). There is no response to light $\mathrm{O} N$, a weak response to acoustic stimulation, and vigorous activation by both combined (inset $B$ ). $(C$ ) An efferent neuron from the medial lobe to the inferior medial protocerebrum was inhibited by acoustic stimuli after presentation of visual and olfactory cues (top trace, inset $C$ ) but excited by sound after flicker and tactile cues (lower trace, inset $C$ ).

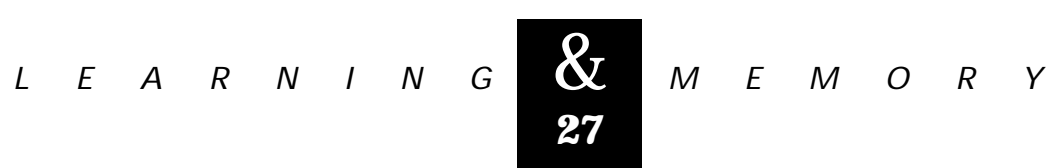


Strausfeld et al.

brum (Schildberger 1981, 1984; Li and Strausfeld 1997).

It may seem curious that the earliest insects were ill equipped for olfaction. But consider the Late Silurian to Early Devonian landscape, devoid of any but the most primitive vegetation. The first insects colonizing the shoreline were presumably littoral detritus feeders, subject to relentless predation by chilopods and chelicerates. The selective pressure for retaining vibration and tactile organs must therefore have been greater than that for the evolution of appendages specialized for detecting distant cues, such as air-borne odorants. The early role of antennae in mechanoreception is even supported by evidence from Drosophila genetics suggesting that the protoinsect possessed leglike head appendages. In Drosophila, alleles of the Hox gene Antennapedia transform the olfactory appendage, the antenna, into the atavistic default appendage, a leg, by inhibiting the expression of genes that program the development of an antenna (Casares and Mann 1998). One hypothesis that can be derived from the neural phylogenetic tree shown in Figure 7 is that a crustaceomorph ancestor to insects and crustaceans possessed a single pair of uniramous leglike appendages equipped for mechanoreception (Strausfeld 1998b). Observations of primitive apterygotes suggest that their antennae retain characters of this crustacean-like ancestor: equipped with sensors typical of a leg for mechanoreception and contact chemoreception but not for far-field olfactory perception.

Interestingly, the transformation of an odorsensitive antenna back to a default mechanosensory appendage has occurred without human intervention. The result of this transformation is seen in certain anosmic terrestrial and freshwater neopterans, particularly among the Hemiptera in which a reduced mechanosensory antenna is accompanied by the absence of olfactory glomeruli and a drastic reduction or even absence of the mushroom body calyces, as in the backswimmer Notonecta (see Fig. $2 \mathrm{H}$ ). This adaptation provides additional evidence that the calyx is not fundamental to mushroom body design but is a specialized neuropil associated with the ability to detect distant airborne odors.

\section{MUSHROOM BODIES AS OLFACTORY}

AND MULTIMODAL INTEGRATORS

Until Vowles's experiments with mushroom body lesioning, the general view of mushroom body function was that they played a major role in integrating olfactory and visual signals and were important for controlling complex behaviors. Their involvement in the integration of several sensory modalities was supported by Jawlowski's (1958, 1960) studies on Hymenoptera describing essential features of the axonal pathways from the optic and antennal lobes to the calyces. Weiss (1981) demonstrated that orthopteran mushroom bodies are supplied by the antennal lobes as well as by a parallel tract of projection neurons from the lobus glomerulatus, which is itself supplied by afferents from chemoreceptors of the mouth parts (Ernst et al. 1977).

Schürmann (1970a,b, 1971) demonstrated in the cricket Achaeta that the dendrites of Kenyon cells can be postsynaptic to olfactory interneuron terminals in the calyces and that Kenyon cell axons are presynaptic to efferent neurons in the lobes. Afferents to the calyces synapse onto at least a sizable subset of Kenyon cell dendrites, although there are more dendrites offering postsynaptic sites than antennal lobe terminals providing presynaptic ones. Together, these publications provide a broad consensus regarding the organization of Kenyon cell dendrites and support the idea that a major role for the mushroom bodies in odor-sensitive neopteran insects is in olfactory processing. This has been demonstrated many times by electrophysiology (e.g., see Burrows et al. 1982; Kanzaki et al. 1989; Laurent and Naraghi 1994). Recent studies, for example, demonstrate that olfactory interneurons show synchronized activity, interpreted as activated neural assemblies, when they encode specific odors (MacLeod and Laurent 1996). Conversely, pharmacologically induced desynchronization impairs the discrimination of similar odorants, suggesting that oscillation synchrony, possibly mediated by the mushroom bodies, is essential for fine detail discrimination (Stopfer et al. 1997).

In addition to their role in odor discrimination, extra- and intracellular recordings have shown that mushroom bodies have another important role: that of integrating different sensory modalities. These include visual (Gronenberg 1986; Homberg 1984), tactile (Schildberger 1984) and acoustic stimuli (Li and Strausfeld 1997, and unpubl.). How do mushroom bodies process different modalities when, as exemplified by the cockroach and cricket, the calyces appear to receive predominantly olfactory inputs? The answer comes from studies of the mushroom body lobes in which syn-

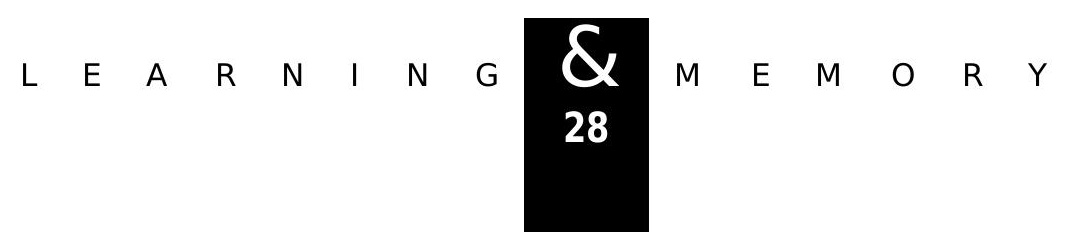


aptic relationships are much more complex than mere connections between Kenyon cell axons and efferent neuron dendrites. Kenyon cell axons in the lobes have both pre- and postsynaptic specializations (Li and Strausfeld 1997) confirming electron microscopical studies showing Kenyon cell axons pre- and postsynaptic to each other, postsynaptic to afferent profiles (Schürmann 1970a,b; Strausfeld 1998a), and having synaptic relationships with fibers that contain dense core vesicles indicative of neuromodulator elements (Frontali and Mancini 1970; Schürmann and Erber 1990; Strausfeld 1998a). There is now abundant evidence that various sensory modalities reach the mushroom body lobes (and calyces) indirectly through other protocerebral neuropils, such as the inferior and superior medial protocerebra. In cockroaches, for example, visual, tactile, and acoustic modalities are carried by afferents that terminate in the vertical and medial lobes (Fig. 8A; see also, Li and Strausfeld 1997, and unpubl.).

The cited studies suggest that mushroom bodies play important roles in multimodal sensory integration, possibly processing many types of sensory signals in conjunction with, or independent of, olfactory inputs (Fig. 8). However, depending on their internal architectures and lobed divisions, mushroom bodies in different insects may mediate a variety of functions. In certain species, such as Drosophila (Ito et al. 1998), the comparatively simple mushroom bodies might serve functions mainly associated with olfactory perception. In phylogenetically basal species, such as Periplaneta, mushroom bodies may serve functions associated with olfaction and, because they receive so many other modalities, they may also play essential roles in a variety of other sensory and motor pathways.

The range of functions is suggested from extracellular recordings. For example, units in the cockroach medial and vertical lobes appear to distinguish mechanical self-stimulation from imposed tactile stimulation. Other units reflect motor actions and are modulated by changes in direction (Mizunami et al. 1993). Lesions of the medial lobes adversely affect place memory (Mizunami et al. 1993). Intracellular recordings ( $\mathrm{Li}$ and Strausfeld 1997; see also Fig. 8) reveal responses to a large range of sensory stimuli and modalities.

The role of mushroom bodies in motor control has been suggested previously by Erber et al. (1987) who stressed the importance of experiments that use focal stimulation or ablation of the mushroom bodies to elicit or abolish specific motor actions. This strategy, introduced by van der Kloot and Williams (1954) and by Huber (1955; see also Wadepuhl 1983), indicates that mushroom bodies might play a pivotal role in coordinating behavioral programs. Likewise, electrical stimulation and lesion experiments suggest the importance of mushroom bodies in specific behavioral repertoires such as courtship (Huber 1959, 1960) and other motor actions (Maynard 1967). An involvement by the mushroom bodies in meeting a variety of behavioral demands has been proposed from studies on honeybees and ants that show enlargement of mushroom body neuropils that results from multitasking by ants (Gronenberg et al. 1996) or, in honeybees, that coincides with hormonally induced changes of the behavioral repertoire (Withers et al. 1993, 1995). In crickets, hormone-dependent increase in the number of Kenyon cells at sexual maturity (Cayre et al. 1994) may also be linked to the expression of new behaviors.

Erber et al. (1987) proposed that mushroom bodies perform at least five discrete computations on sensory inputs and relay the results to distributed areas in the protocerebrum, some of which compare ongoing and past stimuli or form olfactory memory. The five functions summarized from electrophysiological data are: the generation of after-effects in output neurons (Vowles 1964b), which can persist for minutes after the stimulus (Schildberger 1981, 1984; Gronenberg 1987); enhancement of the signal-to-noise ratio of the olfactory stimulus; detection of stimulus combinations; detection of temporal events in an olfactory stimulus; and detection of stimulus sequences.

There is compelling evidence that efferent neurons from the mushroom bodies have contextspecific responses, meaning that the activity of an efferent neuron depends on the accompanying or the immediately preceding sensory stimuli. In the cricket Acheta domesticus, the rate of discharge, or the level of inhibition or excitation of an efferent neuron, can depend on what modalities precede the test stimulus (Schildberger 1984). An efferent neuron can increase its discharge rate from resting when the cercus is stimulated after repeated mechanical stimulation of the antenna. The same neuron decreases its discharge rate from resting when repeated stimulation of the cercus is follow ed by stimulation of the antenna (Schildberger 1981). In Periplaneta, the activity of efferent neurons reacting to one stimulus alone is modified

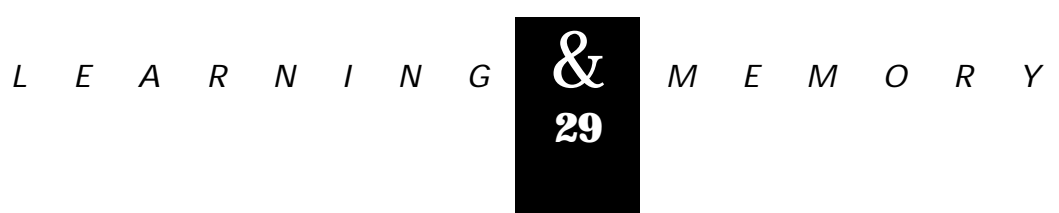


Strausfeld et al.

Figure 9: Relationships between the mushroom body and other parts of the nervous system. (Round-cornered boxes) Sensory organs grouped according to modality. (Shaded boxes) Neuropil regions relatively well investigated. (White boxes) Regions essentially uninvestigated. (Thick shaded lines) Major tracts connecting neuropil regions. (Arrows) Supposed direction of information (omitted where evidence for polarity is lacking). Information about ambient light intensity is received by the ocelli, preprocessed in the ocellar neuropil and sent to the caudal part of the deutocerebrum (posterior slope) via the ocellar nerve (ocellar $n$ ). Visual information is received by the compound eyes and processed in nested retinotopic optic lobe neuropils (lamina, medulla, and lobula/lobula plate) before entering the central brain. The ventro-lateral protocerebrum ( $\mathrm{v}$ I pr) receives visual signals almost exclusively, and thus can be considered to contain the primary optic foci. 0 ther areas [e.g., lateral horn (l ho); superior lateral protocerebrum ( $\mathrm{s} \mid \mathrm{pr}$ ); inferior lateral protocerebrum ( $\mathrm{i} \mid \mathrm{pr})]$ are also supplied by the optic lobes, but they also receive inputs from other sensory neuropils. A direct connection from the medulla and lobula to the calyces is observed in certain $\mathrm{Hy}$ menoptera (dotted arrow). Certain efferents from the lobula/lobula plate project directly to premotor neuropil of the posterior slope. Mechanosensory receptors on the antennae (including Johnston's organ supplying acoustic information in flies and mosquitoes) enter the brain via the antennal nerve (ant $n$ ) terminating in

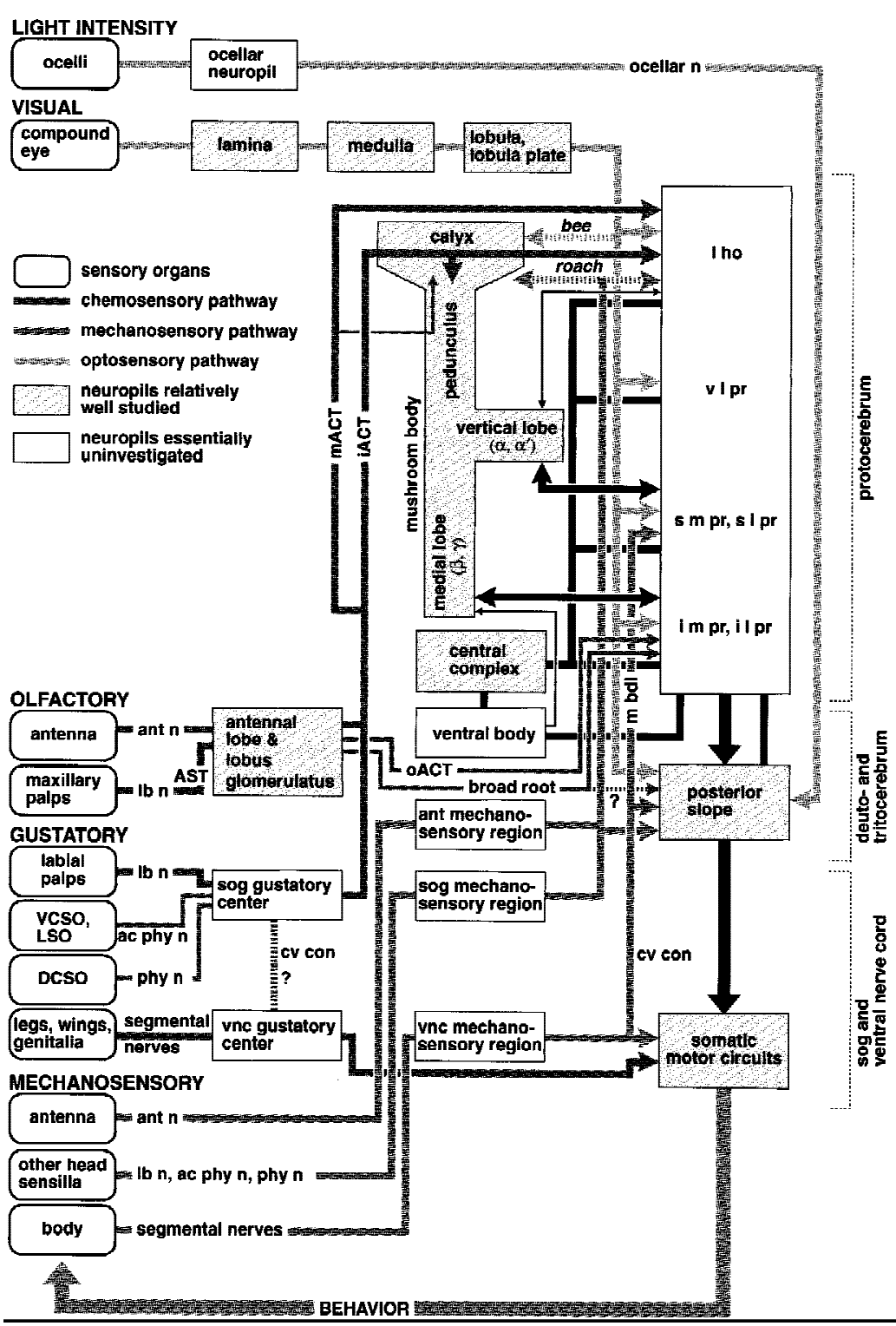
the antennal mechanosensory neuropil (dorsal lobe) of the deutocerebrum. Mechanosensory axons from the head and proboscis project to specific neuropils in suboesophageal ganglion (sog) via labial (lb n), pharyngeal (phy $\mathrm{n}$ ), and accessory pharyngeal (ac phy $\mathrm{n}$ ) nerves. Mechanosensory axons from the body and extremities (wings, legs, genitalia) project to defined regions in the respective thoracic or abdominal neuromere, (vnc) ventral nerve cord. Connections with somatic motor circuits provide appropriate local computations for reflexive motor actions (see Burrows 1992). Tactile and acoustic relays (in crickets, grasshoppers, certain Diptera) reach the brain via the cervical connective (cv con) and median bundle $(\mathrm{m} \mathrm{bdl})$ to reach superior medial protocerebrum (s $\mathrm{m} \mathrm{pr}$ ). Airborne (olfactory) chemical stimuli are detected by the third antennal segment and maxillary palps. The former sends axons through the antennal nerve (ant $n$ ) to the antennal lobe. Axons from the latter enter the suboesophageal ganglion via the labial nerve (lb $\mathrm{n}$ ) and project to the antennal lobe, via the antenno-suboesophageal tract (AST). Olfactory receptor terminals have odortypic segregation to specific glomeruli (Rodriguez and Buchner 1984; Rodriguez and Pinto 1989; Stocker 1994). Contact (gustatory or taste) chemosensory neurons in the labial palps project via the labial nerve $(\mathrm{lb} \mathrm{n})$ to a gustatory center in the sog, which, unlike the antennal lobe, does not show prominent glomerular structures. Gustatory neurons from the ventral cibarial sense organ (VCSO) and the labral sense organ (LSO) project to the gustatory center via the accessory pharyngeal nerve (ac phy $n$ ), and those from the dorsal cibarial sense organ (DCSO ) via the pharyngeal nerve (phy n). In Blattodea and O rthoptera, a second glomerular neuropil, the lobus glomerulatus, receives inputs from the mouthparts (Ernst et al. 1977) and provides axons to the calyces via a parallel strand of the i ACT (W eiss 1981). Gustatory neurons in the fore, middle and hind legs, wings, and female genitalia project to the thoracic and abdominal ganglia (vnc) via respective segmental nerves. It is likely that the somatic

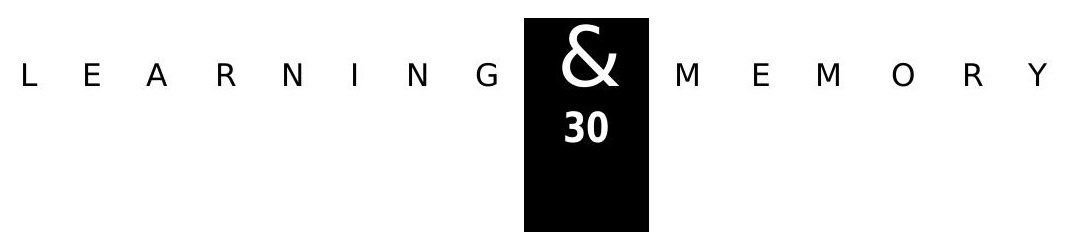


Figure 9: (Continued) gustatory signal is conveyed to the brain via the cervical connective (cv con). Projection neurons from the antennal lobe, lobus glomerulatus, and sog gustatory centers contribute to inner antennocerebral tracts (iACT). These project to the lateral horn (I ho) sending collaterals to the mushroom body calyx (a). Projection neurons in the middle antennocerebral tract (mACT) project directly to the I ho with a small subset of mACT entering the pedunculus and terminating in the calyx. The outer antennocerebral tract (OACT) contains fewer fibers connecting the ant lob and inferior lateral protocerebrum ( $\mathrm{I}$ pr). The broad root (Power 1946) is supposed to contain a few fibers that project posteriorly from the ant lob. Vertical lobes of the mushroom bodies are connected with the anterior region of the superior medial and lateral protocerebra ( $\mathrm{s} \mathrm{m}$ pr and $\mathrm{s} / \mathrm{pr}$ ). Medial lobes are connected to the anterior part of the inferior medial protocerebrum ( $\mathrm{i}$ $\mathrm{m}$ pr). The mushroom bodies receive multimodal sensory information from protocerebral regions to their lobes and send output back to the same neuropil regions. The central complex is connected to many protocerebral regions but has no direct connection with the mushroom bodies nor receives direct information from any primary sensory neuropils. The ventral body is connected to various regions of the protocerebrum and has major connections with the central complex. Mushroom bodies and the central complex possess easily identifiable structures. The surrounding neuropils (lateral horn, ventro-lateral protocerebrum, superior and inferior medial/lateral protocerebra) show a much more ambiguous organization. Although often (erroneously) referred to as diffuse neuropils, these areas do have characteristic but complex fibroarchitectures whose neural networks within and between them are scarcely known. Behavior is accomplished by the organized contraction of muscles resulting in the further stimulation of sensory organs (indicated by feedback loop behavior). Muscles are innervated by motor neurons originating in the sog and in thoracic and abdominal ganglia. In the brain (three pre-oral supraoesophageal ganglia) only the deutocerebrum contains motor neurons, which control antennal movements. The brain's deutocerebrum, and parts of the protocerebrum, possess premotor neuropils that contain dendrites of descending neurons that supply somatic motor circuits. Details of connections between most brain regions and descending neurons are not yet known.

when the stimulus is given with a second stimulus of a different modality (Fig. 8B). Other efferents responding to one modality can be conditionally inhibited or excited to that modality depending on what stimulus combinations immediately precede the test stimulus (Fig. 8C). Experience-associated changes of neuronal activity have also been shown from intracellular recordings from one type of extrinsic neuron in the honeybee $\alpha$ lobe (Pe- 1 ), which has been show $n$ to change its electrophysiological signature to olfactory stimulation during associative conditioning (Mauelshagen 1993). It is not known, how ever, whether such modifications are a consequence of computational events occurring within the mushroom body or at some as yet undefined location between the antennal receptor and the efferent neuron's dendrites.

\section{CONCLUSION: INSECT MUSHROOM BODIES AND THE BRAIN}

Figure 9 summarizes the relationship between the brain and a mushroom body of a generic insect, that is, one endowed with features of both recent (e.g., Apis, Drosophila) and basal taxa (e.g., Periplaneta, Orthoptera, Odonata, Zygoentomata). Shown in Figure 9 are the known pathways that relate mushroom bodies to their afferent supply and to other major brain regions. The four classes of afferents received by the mushroom bodies are
1. Afferents to the mushroom body lobes. These reflect the primitive condition in which mushroom bodies without calyces are supplied by afferents from protocerebral neuropils. For example, the medial lobes of cockroaches are supplied with visual, tactile, and acoustic modalities carried by afferents terminating in them (Fig. 8A; also, Li and Strausfeld 1997, and unpubl.). Comparable extrinsic neurons have been morphologically identified in Drosophila (Ito et al. 1998) and honeybees (Strausfeld 1998a).

2. Afferents to the calyces, originating in the proto- and deutocerebrum, also carry multimodal information (Fig. 8A). Thus, the absence of direct inputs to the calyces from the optic lobes in certain species does not preclude their mushroom bodies from integrating visual information.

3. Afferents to the calyces from the antennal lobes and the lobi glomerulati. Exemplified by Periplaneta, each calyx receives olfactory interneurons from the ipsilateral antennal lobe (Fig. 8C) via the inner antennocerebral tract. Some interneurons projecting from the dorsal lobes (mechanosensory receptor neuropil) send collaterals to the calyx en route to the superior lateral protocerebrum. The ipsilateral lobus glomerulatus in acridids (Ernst et al. 1977) supplies the calyx via the globularis-cerebral tract (Weiss 1981). In Lepidoptera (Kent et al. 1986),

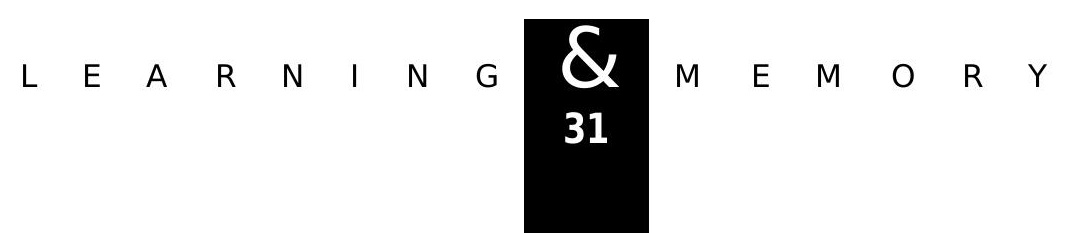


Blattodea, Diptera, and possibly also in Hymenoptera, gustatory glomeruli appear to have become integrated into the antennal lobe, with their projection neurons sharing the inner antennocerebral tract.

4. Afferents from the medulla and lobula of the optic lobes of certain Hymenoptera (honeybees, ant: Gronenberg 1986, 1998) are directly connected to the collar zone of the calyces. Mushroom bodies of Blattodea, Diptera, Lepidoptera, Coleoptera, and Orthoptera appear to lack this annular region suggesting it might be an evolutionary innovation of the Hymenoptera. How ever, as is discussed above, visual information reaches the calyces and lobes of these other groups indirectly via other protocerebral areas.

An important aspect, when discussing the roles of mushroom bodies, is to determine the target areas of their outputs. Figure 9 proposes indirect pathways betw een the mushroom bodies and descending premotor pathways. Two efferent neurons in the blow fly Calliphora have been reported as projecting from the mushroom bodies directly to descending pathways (Strausfeld et al. 1984). In the cockroach Periplaneta one efferent neuron appears to visit a descending neuron ( $\mathrm{Li}$ and Strausfeld 1987a) and one descending neuron sends a short collateral into one lamina at the level of the pedunculus (N.J. Strausfeld, unpubl.). Direct connections between the mushroom bodies and descending neurons have not yet been identified in other species and claims that efferent neurons generally terminate at descending pathways are as yet unsubstantiated. Studies on fruit flies (Ito et al. 1998) suggest that the mushroom bodies are not directly connected to descending neurons, as Kenyon $(1896 a, b)$ originally thought, but instead supply higher order regions of the protocerebrum (Fig. 9). Such an organization supports the thesis of Erber et al. (1987) that associative processing, such as learning and memory, does not necessarily have to occur within the mushroom bodies themselves, but could be performed within distributed regions of the protocerebrum that may or may not include the mushroom bodies proper. Reduced to its basic components, the mushroom body is a system of bifurcated neurons that form elaborate interconnections and networks with one another (Schürmann 1970a,b, 1971; Kaulen et al. 1984), but as a self-contained assemblage it cannot perform any role without close cooperation with other ele- ments of the surrounding neuropils. It seems prudent, therefore, to study the mushroom bodies in the context of the broader landscape of the protocerebrum in which they are but one pair of neuropils connected to many others.

\section{Acknowledgments}

Evolutionary studies were supported by fellowships to N.J.S. from the Simon J. Guggenheim Memorial Foundation and the John D. and Catherine T. MacArthur Foundation. Studies on mushroom bodies are supported by a grant to N.J.S. from the National Science Foundation (IBN 9726957). Peter Kloppenberg provided the preparation for Figure $5 \mathrm{G}$. John S. Edwards supplied living Machilis, and Bruno Bernet supplied living Arctenoë. We are grateful to Camilla Strausfeld, Reinhard Stocker, Martin Heisenberg, and U we Homberg for helpful discussion.

The publication costs of this article were defrayed in part by payment of page charges. This article must therefore be hereby marked "advertisement" in accordance with 18 USC section 1734 solely to indicate this fact.

\section{References}

Ballard, J.W.O., G.J. O Isen, D.P. Faith, W.A. O dgers, D.A. Rowell, and P.W. Atkinson. 1992. Evidence from 12S ribosomal RNA sequences that onychophorans are modified arthropods. Science 258: 1345-1348.

Bicker, G. 1991. Taurine-like immunoreactivity in photoreceptor cells and mushroom bodies: A comparison of the chemical architecture of insect nervous systems. Brain Res. 568: 201-206.

Binet, A. 1894. Contribution à l'étude du système nerveux sousintestinal des insectes. J. Anat. Physiol. 30: 449-580.

Braitenberg, V. 1967. Is the cerebellar cortex a biological clock in the millisecond range? Prog. Brain Res. 25: 334-346.

Bretschneider, F. 1913. Die Centralkörper und die pilzformige Körper im Gehirn der Insekten. Zool. Anz. 41: 560-569.

- - . 1914. Über die Gehirne der Kuchenschabe und des Mehlkäfers. Jena Z. Naturwiss. 52: 269-362.

- - - . 1918. Vergleichenden Untersuchungen an Gehirnen als Beitrag zur Phylogenie der Arthropoden. Naturwiss. Wschr. 33: 665-674.

- - - 1924. Über die Gehirne des Eichenspinners und des Seidenspinners (Lasiocampa quercus L. und Bombyx mori L.). Jena. Z. Naturwiss. 60: 563-578.

Briggs, D.E.G. and D. Collins. 1988. A Middle Cambrian chelicerate from Mount Stephen, British Columbia. Palaeontology 31: 779-798.

Brotz, T.M., N. Bochenek, K. Aronstein, R.H. french-Constant, and A. Borst. 1997. Gamma-aminobutyric

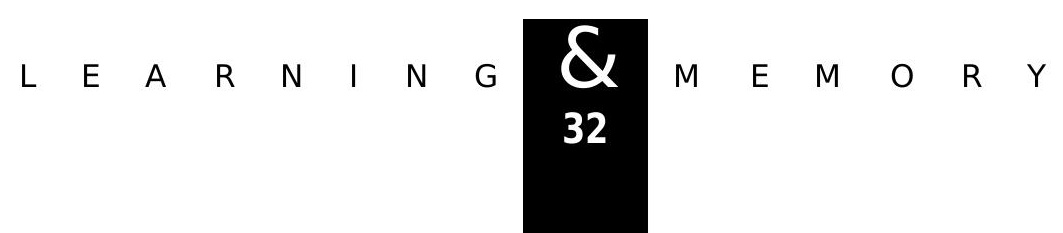


acid receptor distribution in the mushroom bodies of a fly (Calliphora erythrocephala): A functional subdivision of Kenyon cells. J. Comp. Neurol. 383: 42-48.

Brownell, P.H. and R.D. Farley. 1974. The organization of the malleolar sensory system in the solpugid Chambria sp. Tissue Cell 6: 471-485.

Brusca, R.C. and G.J. Brusca. 1990. Invertebrates. Sinauer, Sunderland, MA.

Budd, G.E. 1996. The morphology of O pabinia regalis and the reconstruction of the arthropod stem group. Lethaia 29: 1-14.

Bullock, T.H. and G.A. Horridge. 1965. Structure and function in the nervous systems of invertebrates. Freeman, San Francisco, CA.

Burrows, M.J. 1992. Local circuits for the control of leg movements in insects. Trends Neurosci. 6: 226-232.

Burrows, M., J. Boeckh, and J. Esslen. 1982. Physiological and morphological properties of interneurones in the deutocerebrum of male cockroaches which respond to female pheromone. J. Comp. Physiol. (A) 145: 447-457.

Cajal, S.R. and F. de Castro. 1933. Elementos de técnica micrográfica del sistema nervioso. Tipografía Artística. Madrid, Spain.

Callaerts, P., G. Halder, and W.J. Gehring. 1997. Pax-6 in development and evolution. Annu. Rev. Neurosci.

20: 483-532.

Casares, F. and R.S. Mann. 1998. Control of antennal versus leg development in Drosophila. Nature 392: 723-726.

Cayre, M.C., C. Strambi, and A. Strambi. 1994. Neurogenesis in an adult brain and its hormonal control. Nature 368: 57-59.

Chapman, B. and M.P. Stryker. 1992. O rigin of orientation tuning in the visual cortex. Curr. Opin. Neurobiol. 2: 498-501.

Connolly, J.B., J.H. Roberts, D. Armstrong, K. Kaiser, M. Forte, T. Tully, and C.J. O 'Kane. 1996. Associative learning disrupted by impaired Gs signaling in Drosophila mushroom bodies. Science 274: 2104-2107.

Conway Morris, S. 1979. Middle Cambrian polychaetes from the Burgess Shale of British Columbia. Philos. Trans. R. Soc. Lond. B. 285: 227-274.

Davis, R. 1993. Mushroom bodies and Drosophila learning. Neuron 111: 1-14.

de Belle, J.S. and M. Heisenberg. 1994. Associative odor learning in Drosophila abolished by chemical ablation of mushroom bodies. Science 263: 692-695.

de Mellon, F., V. Alones, and M.D. Lawrence. 1992.
Anatomy and fine structure of neurons in the deutocerebral projection pathway of the crayfish olfactory system. J. Comp. Neurol. 321: 93-111.

Dujardin, F. 1850. M émoire sur le système nerveux des insectes. Ann. Sci. Nat. Zool. 14: 195-206.

- - . 1853. Q uelques observations sur les abeilles et particulièrement sur les actes qui, chez ces insectes peuvent être rapportés à l'intelligence. Ann. Sci. Nat. Zool. 18: $231-240$.

Elofsson, R. and R.R. Hessler. 1990. Central nervous system of Hutchinsoniella macracantha (Cephalocarida). J. Crust. Biol. 10: 423-439.

Elphick, M.A., R.C. Rayne, V. Riveros-M oreno, A. M oncada, and M. O'Shea. 1995. Nitric oxide synthase in locust olfactory interneurons. J. Exp. Biol. 198: 821-829.

Erber, J., T. Masuhr, and R. Menzel. 1980. Localization of short-term memory in the brain of the bee, Apis mellifera. Physiol. Entomol. 5: 343-358.

Erber, J., U. Homberg, and W. Gronenberg. 1987. Functional roles of the mushroom bodies in insects. In Arthropod brain: Its evolution, development, structure, and functions (ed. A.P. Gupta), pp. 485-511. Wiley, New York, NY.

Ernst, K.-D., J. Boeckh, and V. Boeckh. 1977 A neuroanatomical study on the organization of the central antennal pathway in insects. II. Deutocerebral connections in Locusta migratoria and Periplaneta americana. Cell Tissue Res. 176: 285-308.

Fahrenbach, W.H. 1979. The brain of the horseshoe crab (Limulus polyphemus). III. Cellular and synaptic organization of the corpora pedunculata. Tissue \& Cell 11: 162-200.

Faivre, E. 1857. Du cerveau des dytisques consideré dans ses rapports avec la locomotion. Ann. Sci. Nat. Zool. 8: 245-274.

Flögel, J.H.L. 1876. Über den feineren Bau des Arthropodengehirns. Tagesbl. Versamml. dtschr. Naturforsch. Ärzte 49: 115-120.

--- . 1878. Über die einheitlichen Bau des Gehirns in den verschiedenen Insecten-O rdnungen. Z. Wiss. Zool. 30: 556-592.

Forel, A.-H. 1874. Les fourmis de la Suisse: Systématique, notices anatomiques et physiologiques, architecture, distribution géographique, nouvelles expériences et observations de moeurs. Neue Denkschr. Allg. Schweiz. Gesellschaft Gesammten Naturwiss. 26: 1-452.

Friedrich, M. and D. Tautz. 1995. Ribosomal DNA phylogeny of the major extant arthropod classes and the evolution of myriapods. Nature 376: 165-167.

Frontali, N. and K.A. Norberg. 1966. Catecholamine 


\section{Strausfeld et al.}

containing neurons in the cockroach brain. Acta Physiol. Scand. 66: 243-244.

Frontali, N. and G. Mancini. 1970. Studies on the neuronal organization of cockroach corpora pedunculata. J. Insect Physiol. 16: 2293-2301.

Gaffin, D.D. and P.H. Brownell. 1997. Response properties of chemosensory peg sensilla on the pectines of scorpions. J. Comp. Physiol. A. 181: 291-300.

Goll, W. 1967. Strukturuntersuchungen am Gehirn von Formica. Z. Morphol. O ekol. Tiere. 59: 143-210.

Gronenberg, W. 1986. Physiological and anatomical properties of optical input-fibers to the mushroom body of the bee brain. J. Insect Physiol. 32: 695-704.

- - - 1987. Anatomical and physiological properties of feedback neurons of the mushroom bodies in the bee brain. Exp. Biol. 46: 115-125.

- - . 1998. Comparing ant mushroom bodies: The impact of living conditions, learning, and experience. In New neuroethology on the move. Proceedings of the 26th Göttingen Neurobiology Conference (ed. N. Elsner and R. Wehner), vol 1, p. 333. Thieme, Stuttgart, Germany.

Gronenberg, W., S. Heeren, and B. Hölldobler. 1996. Age-dependent and task-related morphological changes in the brain and the mushroom bodies of the ant Camponotus floridanus. J. Exp. Biol. 199: 2011-2019.

Hanström, B. 1926. U ntersuchungen über die relative Grösse der Gehirnzentren verschiedener Arthropoden unter Berücksichtigung der Lebensweise. Z. Mikr. Anat. Zellforsch. 7: 135-190.

- - - 1928. Vergleichende Anatomie des Nervensystems der Wirbellosen Tiere. Springer, Berlin, Germany.

Heisenberg, M. 1980. Mutations of brain structure and function: What is the significance of the mushroom bodies for behavior. In Development and neurobiology of Drosophila (ed. O. Siddiqi, P. Babu, L. M. Hall, and J. C. Hall), pp. 373-390. Plenum Press, New York, NY.

---.1994 . Central brain function in insects: Genetic studies on the mushroom bodies and central complex in Drosophila. Fortschr. Zool. 39: 30-39.

- - - 1998. What do mushroom bodies do for the insect brain? Learn. \& Mem. (this issue).

Heisenberg, M., A. Borst, S. Wagner, and D. Byers. 1985. Drosophila mushroom body mutants are deficient in olfactory learning. J. Neurogenet. 2: 1-30.

Hennig, W. 1966. Phylogenetic systematics. (translated by D.D. Davis and R. Zangerl). University of Illinois Press, U rbana, IL.
Holmgren, N. 1909. Termitenstudien. K. Svenska Vetensk Akad. Handl. 44: 1-215.

- - - . 1916. Zur vergleichenden Anatomie des Gehirns von Polychaeten, O nychophoren, Xiphosuren, Arachniden, Crustaceen, M yriapoden, und Insekten. K. Svenska Vetensk. Akad. Handl. 56: 1-303.

Homberg, U. 1984. Processing of antennal information in extrinsic mushroom body neurons of the bee brain. J. Comp. Physiol. A 154: 825-836.

Homberg, U., R.A. M ontague, and J.G. Hildebrand. 1989. Anatomy of antenno-cerebral pathways in the brain of the sphinx moth Manduca sexta. Cell Tissue Res. 254: 255-281.

Huber, F. 1955. Über die Funktion der Pilzkörper (Corpora pedunculata) beim Gesang der Keulenheuschrecke Gomphocerus rufus L. (Acridiidae). Naturwissenschaften 20: $566-567$.

- - . 1959. Auslösung von Bewegungsmustern durch elektrische Reizung des $O$ berschlundganglions bei O rthopteran (Saltatoria; Gryllidae, Acridiidae). Zool. Anz. 23: 248-269.

- - - 1960. Untersuchungen über die Funktion des Zentralnervensystems und insbesondere des Gehirns bei der Fortbewegung und der Lauterzeugung der Grillen. Z. Vergl. Physiol. 44: 60-132.

Ito, K., W. Awano, K. Suzuki, Y. Hiromi, and D. Yamamoto. 1997. The Drosophila mushroom body is a quadruple structure of clonal units each of which contains a virtually identical set of neurones and glial cells. Development 124: 761-771.

Ito, K., K. Suzuki, P. Estes, M. Ramaswami, D. Yamamoto, and N.J. Strausfeld. 1998. The organization of extrinsic neurons and their implications in the functional roles of the mushroom bodies in Drosophila melanogaster Meigen. Learn. $\& M$ em. (this issue).

Jawlowski, H. 1936. Über die Gehirnbau der Käfer. Z. Morphol. Ö kol. 32: 67-91.

- - - . 1954. Über die Struktur des Gehirns bei Saltatoria. Ann. Univ. Marie Curie-Sklodowska 8: 403-450.

- - . 1958. Nerve tracks in bee (Apis mellifera) running from the sight and antennal organs to the brain. Ann. Univ. Marie Curie-Sklodowska (C) 12: 307-323.

$---.1959 a$. O $n$ the brain structure of the Ichneumonidae. Bull. Acad. Polon. Sci. 3: 123-125.

--1 1959b. The structure of the corpora pedunculata in Aculeata (Hymenoptera). Folia Biol. (Lublin) 7: 61-70.

- - . 1960. On the brain structure of the Symphyta (Hymenoptera). Bull. Acad. Polon. Sci. 8: 265-268. 
Jonescu, C.N. 1909. Vergleichende Untersuchungen über das Gehirn der Honigbiene. Jena Z. Naturwiss. 45: 111-180.

Kambhampati, S. 1996. A phylogeny of cockroaches and related insects based on DNA sequence of mitochondrial RN A genes. Proc. Natl. Acad. Sci. 92: 2017-2020.

Kandel, E. and T. Abel. 1995. Neuropeptides, adenylyl cyclase, and memory storage. Science 268: 825-826.

Kanzaki, R., E.A. Arbas, N.J. Strausfeld, and J.G. Hildebrand. 1989. Physiology and morphology of projection neurons in the antennal lobe of the male moth Manduca sexta. J. Comp. Physiol. A 165: 427-453.

Kaulen, P., J. Erber, and P. Mobbs. 1984. Current source-density analysis in the mushroom bodies of the honey bee (Apis mellifera carnica). J. Comp. Physiol. A. 154: 569-582.

Kent, K.C., I.D. Harrow, P. Q uartararo, and J.G. Hildebrand. 1986. An accessory olfactory pathway in Lepidoptera: The labial pit organ and its central projection in Manduca sexta and certain other sphinx moths and silk moths. Cell Tissue Res. 245: 237-245.

Kenyon, F.C. 1896a. The meaning and structure of the so-called "mushroom bodies" of the hexapod brain. Am. Naturalist 30: 643-650.

$---.1896 \mathrm{~b}$. The brain of the bee. A preliminary contribution to the morphology of the nervous system of the Arthropoda. J. Comp. Neurol. 6: 133-210.

Klemm, N. 1983. Monoamine-containing neurons and their projections in the brain (supraoesophageal ganglion) of cockroaches. Cell Tissue Res. 229: 379-402.

Kukalová-Peck, L. 1991. Fossil history and the evolution of hexapod structures. In The insects of Australia. vol 1. pp. 141-180, Melbourne University Press, Melbourne, Australia.

Kuljis, R.O. and P. Rakic. 1990. Hypercolumns in primate visual cortex can develop in the absence of cues from photoreceptors. Proc. Natl. Acad. Sci. 87: 5303-5305.

Labandeira, C.C. and B.S. Beal. 1990. Arthropod terrestriality. In Arthropod paleobiology: Short courses in paleontology 3 (ed. S.J. Culver), pp. 214-256. Paleontological Society, Washington, D.C.

Labandeira, C.C. and J.J. Sepkoski. 1993. Insect diversity in the fossil record. Science 261: 310-315.

Labandeira, C.C., B.S. Beal, and F.M. Hueber. 1988. Early insect diversification: Evidence from a Lower Devonian bristletail from Quebec. Science 242: 913-916.

Laurent, G. 1997. Olfactory processing: Maps, time and codes. Curr. Opin. Neurobiol. 7: 547-553.

Laurent, G. and M. Naraghi. 1994. O dorant-induced oscillations in the mushroom bodies of the locust. J. Neurosci. 14: 2993-3004.

Leydig, F. 1864. Vom Bau des tierischen Körpers, vol. 1. Verlag der H. Laupp'schen Buchhandlung, Tübingen, Germany.

Li, Y.-S. and N.J. Strausfeld. 1997. Morphology and sensory modality of mushroom body efferent neurons in the brain of the cockroach, Periplaneta americana. J. Comp. Neurol. 387: 631-650.

Linsenmair, K.E. 1987. Kin recognition in subsocial arthropods, in particular in the desert isopod Hemilepistus reaumuri. In Kin recognition in animals (ed. D.J.C. Fletcher and C.D. Michener), pp. 121-208. Wiley Press, Chichester, NY.

MacAlpine, J.F. 1989. Manual of nearctic Diptera 3. Agriculture Canada Monograph 32. Canadian Gov. Publ. Center, Quebec, Canada.

MacLeod, K. and G. Laurent. 1996. Distinct mechanisms for synchronization and temporal patterning of odor-encoding neural assemblies. Science 274: 976-979.

Maddison, W.P. and D.R. Maddison. 1992. MacClade, Version 3: Analysis of phylogeny and character evolution. Sinauer Associates, Sunderland, MA.

Malun, D., U. Waldow, D. Kraus, and J. Boeckh. 1993. Connections between the deutocerebrum and the protocerebrum, and neuroanatomy of several classes of deutocerebral projection neurons in the brain of male Periplaneta americana. J. Comp. Neurol. 329: 143-162.

Mauelshagen, J. 1993. Neural correlates of olfactory learning paradigms in an identified neuron in the honey bee brain. $J$. Neurophysiol. 69: 609-625.

Maynard, D.M. 1967. Electrical activity in the cockroach cerebrum. Nature 177: 529-530.

Menzel, R., J. Erber, and T. Masuhr. 1974. Learning and memory in the honey bee. In Experimental analysis of insect behaviour (ed. L. Barton Browne), pp 195-217. Springer, Heidelberg, Germany.

Mizunami, M., J.M. W eibrecht, and N.J. Strausfeld. 1993. A new role for the insect mushroom bodies: Place memory and motor control. In Biological neural networks in invertebrate neuroethology and robotics (ed. R.D. Beer, R. Ritzmann, and T. McKenna), pp. 199-225. Academic Press, Cambridge, MA.

Mizunami, M., M. Iwasaki, M. Nishikawa, and R. O kada. 1997. Modular structure in the mushroom body of the cockroach. Neurosci. Lett. 229: 153-156.

Mobbs, P.G. 1982. The brain of the honey bee Apis mellifera. 1. The connections and spatial organizations of the mushroom bodies. Philos. Trans. R. Soc. Lond. B. 298: 309-354. 


\section{Strausfeld et al.}

--1 1984. Neural networks in the mushroom bodies of the honey bee. J. Insect Physiol. 30: 43-58.

Muller, R. 1996. A quarter of a century of place cells. Neuron 17: 813-822.

Nässel, D.R. and R. Elofsson. 1987. Comparative anatomy of the crustacean brain. In Arthropod brain: Its evolution, development, structure, and functions (ed. A.P. Gupta), pp. 111-133. Wiley, New York, NY.

Nighorn, A., M.J. Healy, and R.L. Davis. 1991. The cyclic AMP phosphodiesterase encoded by the Drosophila dunce gene is concentrated in the mushroom body neuropil. Neuron 6: 455-467.

Patterson, C. 1982. Morphological characters and homology. In Problems of phylogenetic reconstruction (ed. K.A. Josey and A.E. Friday), pp. 21-74. Academic Press. London, UK.

Pearson, L. 1971. The corpora pedunculata of Sphinx ligustri L. and other Lepidoptera: An anatomical study. Philos. Trans. R. Soc. Lond. B. 259: 477-516.

Pflugfelder, O. 1937. Vergleichende-anatomische, experimentelle, und embryologische Untersuchungen über das Nervensystem und die Sinnesorgane der Rhynchoten. Zoologica Stuttgart 34: 1-102.

Power, M.E. 1946. The antennal centers and their connections with the brain of Drosophila melanogaster. J. Comp. Neurol. 85: 485-509.

Quinn, W.G., W.A. Harris, and S. Benzer. 1974. Conditioned behavior in Drosophila melanogaster. Proc. Natl. Acad. Sci. 71: 708-712.

Rabe, W. 1953. Beiträge zum O rientierungsproblem der W asserwanzen. Z. vergl. Physiol. 35: 300-325.

Rodriguez, V. and E. Buchner. 1984. 2-Deoxyglucose mapping of odor-induced neuronal activity in the antennal lobes of Drosophila melanogaster. Brain Res. 324: 374-378.

Rodriguez, V. and L. Pinto. 1989. The antennal glomerulus as a functional unit of odor coding in Drosophila melanogaster. In Neurobiology of sensory systems (ed. R.N. Singh and N.J. Strausfeld), pp. 387-396. Plenum Press, New York, NY.

Rybak, J. and R. Menzel. 1993. Anatomy of the mushroom bodies in the honey bee brain: The neuronal connections of the alpha-lobe. J. Comp. Neurol. 334: 444-465.

Sánchez y Sánchez, D. 1933. Contribution á la connaissance de la structure des corps fongiformes (calices) et leurs pédicules chez la blatte commune (Stylopyga (Blatta) orientalis). Trab. Lab. Invest. Biol. Univ. Madrid 28: 149-185.

Sandeman, D.C., G. Scholtz, and R.E. Sandeman. 1993. Brain evolution in decapod Crustacea. J. Exp. Zool.

265: 112-133.

Schildberger, K. 1981. Some physiological features of mushroom body linked fibers in the house cricket brain. Naturwissenschaften 67: 623.

- - . 1984. Multimodal interneurons in the cricket brain: Properties of identified extrinsic mushroom body cells. J. Comp. Physiol. A 154: 71-79.

Schürmann, F.W. 1970a. Über die Struktur der Pilzkörper des Insektengehirns. I. Synapsen im Pedunculus. Z. Zellforsch. 103: 365-381.

- - . 1970b. Über die Struktur der Pilzkörper des Insektengehirns. II. Synaptische Schaltungen im Alpha-lobus des Heimchens Acheta domesticus L. Z. Zellforsch. 127: $240-257$.

- - . 1971. Synaptic contacts of association fibers in the brain of the bee. Brain Res. 26: 169-176.

- - - . 1973. Über die Struktur der Pilzkörper des Insektengehirns. III. Die Anatomie der Nervenfasern in der Corpora pedunculata bei Acheta domesticus L. (O rthoptera): Eine Golgi-Studie. Z. Zellforsch. Mikr. Anat. 145: 247-285.

- - - 1974. Bemerkungen zur Funktion der Corpora pedunculata im Gehirn der Insekten aus morphologischer Sicht. Exp. Brain Res. 19: 406-432.

- - - 1995. Common and special features of the nervous system of O nychophora: A comparison with Arthropoda, Annelida, and some other invertebrates. In The nervous systems of invertebrates: An evolutionary and comparative approach (ed. O. Breidbach and W. Kutsch), pp. 139-158. Birkhäuser, Basel, Switzerland.

Schürmann, F.W . and N. Klemm. 1973. Zur monoamine Verteilung in den Corpora pedunculata des Gehirn von Acheta domesticus L. (O rthoptera, Insecta): Histochemische Untersuchungen, mit Vergleichen zur Struktur und Ultrastruktur. Z. Zellforsch. 136: 393-414.

Schürmann, F.W. and J. Erber. 1990. FM RFamide-like immunoreactivity in the brain of the honey bee (Apis mellifera). A light and electron microscopical study. Neurosciences 38: 797-807.

Shepherd, G.M. and C.A. Greer. 1998. Olfactory bulb. In The synaptic organization of the brain (ed. G.M. Shepherd), pp. 159-204. Oxford University Press, Oxford, UK.

Sivinski, J. 1989. Mushroom body development in nymphalid butterflies: A correlate to learning? J. Insect Behav. 2: 277-283.

Stocker, R.F.M. 1994. The organization of the chemosensory system in Drosophila melanogaster. Cell Tissue Res. 275: 3-26.

Stopfer, M., S. Bhagavan, B.H. Smith, and G. Laurent. 1997. Impaired odour discrimination on desynchronization of odour-encoding neural assemblies. Nature 390: 70-74. 
Strausfeld, N.J. 1976. Atlas of an insect brain. Springer, Heidelberg, Germany.

- - . 1998a. The insect mushroom body: A uniquely identifiable neuropil. In Identified neurons in model systems (ed. J.L. Leonard), Harvard University Press, Cambridge, MA (in press).

$---.1998 b$. Crustacean-insect relationships: The use of brain characters to derive phylogeny amongst segmented invertebrates. Brain, behavior and evolution 52: (in press).

- - . 1998c. The insect mushroom body: Longitudinal organization may support discrete functional roles. In New neuroethology on the move. Proceedings of the 26th Göttingen Neurobiology Conference (ed. N. Elsner and R. Wehner), Vol. 2, p.516. Thieme, Stuttgart, Germany.

Strausfeld, N.J., U. Bassemir, R.N. Singh, and J.P. Bacon. 1984. O rganizational principles of outputs from dipteran brains. J. Insect Physiol. 30: 73-93.

Strausfeld, N.J. and F.G. Barth. 1993. Two visual systems in one brain: Neuropils serving the secondary eyes of the spider Cupiennius salei. J. Comp. Neurol. 328: 55-63.

Strausfeld, N.J., E.K. Buschbeck, and R.S. Gomez. 1995. The arthropod mushroom body: Its roles, evolutionary enigmas and mistaken identities. In The nervous systems of invertebrates: An evolutionary and comparative approach (ed. 0 . Breidbach and W. Kutsch), pp. 349-381, Birkhäuser, Basel, Switzerland.

Swofford, D.L. 1992. PAUP: Phylogenetic analysis using parsimony, version 3. OS. (distributed by the Center for Biodiversity, Illinois N atural History Survey, Champagne, IL 61820.

van der Kloot, W.G. and C.M. Williams. 1954. Cocoon construction by the Cecropiea silkworm. III. The alteration of spinning behavior by chemical and surgical techniques. Behavior 6: 233-255.

Viallanes, H. 1887a. Études histologiques et organologiques sur les centres nerveux et les organes des sens des animaux articulés. Cinqième mémoire. I. Le cerveau du criquet (O edipoda coerulesence et Caloptenus italicus) Ann. Sci. Nat. Zool. 2: 1-98.

$---.1887 b$. Études histologiques et organologiques sur les centres nerveux et les organes des sens des animaux articulés. Cinqième mémoire. 4 . Le cerveau de la guêpe (Vespa crabro et V. vulgaris). Ann. Sci. Nat. Zool. 4: 5-100.

- - - 1893. Études histologiques et organologiques sur les centres nerveux et les organes des sens des animaux articulés. Cinqième mémoire. 6 . Le cerveau de la limule (Limulus polyphemus). Ann. Sci. Nat. Zool. 14: 405-456.

von Alten, H. 1910. Zur Phylogenie des

Hymenopterengehirns. Jena Z. Naturwiss. 46: 511-590.

Vowles, D.M. 1955. The structure and connections of the corpora pedunculata in bees and ants. Q. J. Microsc. Sci. 96: 239-255.

- - . 1964a. Olfactory learning and brain lesion in the wood ant (Formica rufa). J. Comp. Physiol. Psychol. 58: 105-111.

- - - 1964b. Models and the insect brain. In Neural theory and modeling (ed. R.F. Reiss), pp. 377-399. Stanford University Press, Palo Alto, CA.

Wadepuhl, M. 1983. Control of grasshopper singing behavior by the brain: Responses to electrical stimulation. $Z$. Tierpsychol. 26: 1003-1017.

W eiss, M.J. 1974. Neuronal connections and the function of the corpora pedunculata in the brain of the American cockroach, Periplaneta americana (L). J. Morphol.

142: 21-69.

--- 1981. Structural patterns in the corpora pedunculata of Orthoptera: A reduced silver analysis. J. Comp. Neurol. 203: 515-525.

Wheeler, W.C., P. Cartwright, and C.Y. Hayashi. 1993. Arthropod phylogeny: A combined approach. Cladistics 9: 1-39.

Whitington, P.M., T. M eier, and P. King. 1991. Segmentation, neurogenesis and formation of early axonal pathways in the centipede Ethmostigmus rubripes (Brandt). Wilhelm Roux's Arch. Dev. Biol. 199: 349-363.

Whittington, H.B. 1978. The lobopod animal Aysheaia pedunculata Walcott, Middle Cambrian, Burgess Shale, British Columbia. Philos. Trans. R. Soc. Lond. B. 284: 165-197.

Withers, G.S., S.E. Fahrbach, and G.E. Robinson. 1993. Selective neuroanatomical plasticity and division of labour in the honey bee. Nature 364: 238-240.

- - . 1995. Effects of experience and juvenile hormone on the organization of the mushroom bodies of honey bees. J. Neurobiol. 26: 130-144.

Yang, M.Y., J.D. Armstrong, J. Vilinsky, N.J. Strausfeld, and K. Kaiser. 1995. Subdivision of the Drosophila mushroom bodies by enhancer-trap expression patterns. Neuron 15: $45-54$.

Received February 11, 1998; accepted in revised form June 12, 1998. 


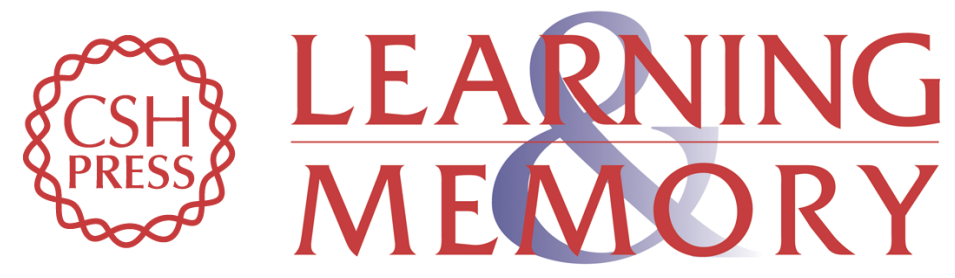

Evolution, Discovery, and Interpretations of Arthropod Mushroom Bodies

Nicholas J. Strausfeld, Lars Hansen, Yongsheng Li, et al.

Learn. Mem. 1998, 5:

Access the most recent version at doi:10.1101//m.5.1.11

References This article cites 103 articles, 14 of which can be accessed free at: http://learnmem.cshlp.org/content/5/1/11.full.html\#ref-list-1

License

Email Alerting Receive free email alerts when new articles cite this article - sign up in the box at the Service top right corner of the article or click here. 